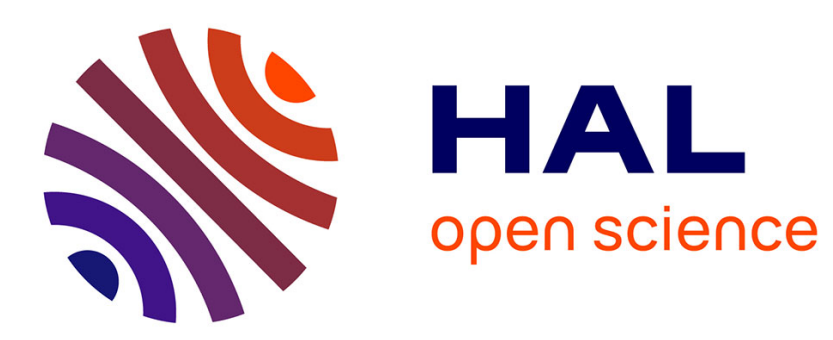

\title{
On the promotional effect of $\mathrm{Pd}$ on the propene-assisted decomposition of $\mathrm{NO}$ on chlorinated $\mathrm{Ce0.68} \mathrm{Zr0.32} \mathrm{O} 2$
}

Cyril Thomas, Olivier Gorce, Céline Fontaine, Jean-Marc Krafft, Françoise Villain, Gérald Djéga-Mariadassou

\section{- To cite this version:}

Cyril Thomas, Olivier Gorce, Céline Fontaine, Jean-Marc Krafft, Françoise Villain, et al.. On the promotional effect of $\mathrm{Pd}$ on the propene-assisted decomposition of $\mathrm{NO}$ on chlorinated $\mathrm{Ce} 0.68 \mathrm{Zr} 0.32$ O2. Applied Catalysis B: Environmental, 2006, 63, pp.201-214. hal-00181040

\author{
HAL Id: hal-00181040 \\ https://hal.science/hal-00181040
}

Submitted on 23 Oct 2007

HAL is a multi-disciplinary open access archive for the deposit and dissemination of scientific research documents, whether they are published or not. The documents may come from teaching and research institutions in France or abroad, or from public or private research centers.
L'archive ouverte pluridisciplinaire HAL, est destinée au dépôt et à la diffusion de documents scientifiques de niveau recherche, publiés ou non, émanant des établissements d'enseignement et de recherche français ou étrangers, des laboratoires publics ou privés. 
On the promotional effect of Pd on chlorinated $\mathrm{Ce}_{0.68} \mathrm{Zr}_{0.32} \mathrm{O}_{2}$

6 Cyril Thomas*, Olivier Gorce ${ }^{1}$, Céline Fontaine, Jean-Marc Krafft, Françoise Villain ${ }^{2}$ and 7 Gérald Djéga-Mariadassou

Laboratoire de Réactivité de Surface, UMR CNRS 7609, Université Pierre et Marie Curie, 4

Place Jussieu, Case 178, 75252 Paris cedex 05, France

$11{ }^{1}$ Present address: Renault sas, Centre Technique de Lardy, 1 allée Cornuel, 91510 Lardy,

12 France

13 22aboratoire de Chimie Inorganique et Matériaux Moléculaires, UMR CNRS 7071, 14 Université Pierre et Marie Curie, 4 Place Jussieu, 75252 Paris cedex 05, France

16 Running title: $\mathrm{C}_{3} \mathrm{H}_{6}$-assisted decomposition of $\mathrm{NO}$ on $\mathrm{PdO}_{\mathrm{x}} / \mathrm{Ce}_{0.68} \mathrm{Zr}_{0.32} \mathrm{O}_{2}$ catalysts

17

$18 *$ To whom correspondence should be addressed:

Dr. Cyril Thomas

20 Laboratoire de Réactivité de Surface, UMR CNRS 7609, case 178, Université P. et M. Curie,

214 Place Jussieu 75252 Paris Cedex 05, France

22 e-mail: cthomas@ccr.jussieu.fr

23 Tel: + 33144273630

24 Fax: + 33144276033 


\section{Abstract:}

The Selective Catalytic Reduction (SCR) of $\mathrm{NO}_{\mathrm{x}}$ assisted by propene is investigated on $\mathrm{Pd} / \mathrm{Ce}_{0.68} \mathrm{Zr}_{0.32} \mathrm{O}_{2}$ catalysts $(\mathrm{Pd} / \mathrm{CZ})$, and is compared, under identical experimental

4 conditions, with that found on a $\mathrm{Pd} / \mathrm{SiO}_{2}$ reference catalyst. Physico-chemical characterisation 5 of the studied catalysts along with their catalytic properties indicate that $\mathrm{Pd}$ is not fully 6 reduced to metallic $\mathrm{Pd}$ for the $\mathrm{Pd} / \mathrm{CZ}$ catalysts. This study shows that the incorporation of $\mathrm{Pd}$ to $\mathrm{CZ}$ greatly promotes the reduction of $\mathrm{NO}$ in the presence of $\mathrm{C}_{3} \mathrm{H}_{6}$. These catalysts display very stable deNO $\mathrm{x}_{\mathrm{x}}$ activity even in the presence of $1.7 \%$ water, the addition of which induces a reversible deactivation of about $10 \%$. The much higher $\mathrm{N}_{2}$ selectivity obtained on $\mathrm{Pd} / \mathrm{CZ}$ suggests that the lean deNO $\mathrm{x}_{\mathrm{x}}$ mechanism occurring on these catalysts is different from that occurring on $\mathrm{Pd}^{0} / \mathrm{SiO}_{2}$. A detailed mechanism is proposed for which $\mathrm{CZ}$ achieves both NO oxidation to $\mathrm{NO}_{2}$ and $\mathrm{NO}$ decomposition to $\mathrm{N}_{2}$, whereas $\mathrm{PdO}_{\mathrm{x}}$ activates $\mathrm{C}_{3} \mathrm{H}_{6}$ via ad- $\mathrm{NO}_{2}$ species, intermediately producing $\mathrm{R}-\mathrm{NO}_{\mathrm{x}}$ compounds that further decompose to $\mathrm{NO}$ and $\mathrm{C}_{\mathrm{x}} \mathrm{H}_{\mathrm{y}} \mathrm{O}_{\mathrm{z}}$. The role of the latter oxygenates is to reduce $\mathrm{CZ}$ to provide the catalytic sites responsible for $\mathrm{NO}$ decomposition. The proposed $\mathrm{C}_{3} \mathrm{H}_{6}$-assisted $\mathrm{NO}$ decomposition mechanism stresses the key role of $\mathrm{NO}_{2}, \mathrm{R}-\mathrm{NO}_{\mathrm{x}}$ and $\mathrm{C}_{\mathrm{x}} \mathrm{H}_{\mathrm{y}} \mathrm{O}_{\mathrm{z}}$ as intermediates of the SCR of

$17 \quad \mathrm{NO}_{\mathrm{x}}$ by hydrocarbons.

Key Words: CO-FTIR, XANES, Lean deNO ${ }_{x}$, Mechanism, $\mathrm{C}_{3} \mathrm{H}_{6}, \mathrm{Pd}$ catalysts, Ceria21 Zirconia, TPD of $\mathrm{NO}_{\mathrm{x}}$ 


\section{Introduction}

A tremendous number of investigations have been made within the past decades to develop catalysts capable of decreasing the emissions of air pollutants such as carbon monoxide $(\mathrm{CO})$, hydrocarbons $(\mathrm{HC})$ and nitrogen oxides $\left(\mathrm{NO}_{\mathrm{x}}\right)$ from automotive gas exhausts [1-6]. The development of improved catalysts to meet the ever more stringent emissions standards is, however, still of key importance. To achieve this goal, the most promising means would obviously be to find a catalytic system that could directly decompose NO over a wide range of temperatures as pointed out by Pârvulescu et al. in a rather recent review [4]. Although a large number of catalysts have already been tested, no such system has as yet been found.

Three-Way Catalysts (TWC) were among the first possibilities investigated for lean $\mathrm{NO}_{\mathrm{x}}$ abatement in car exhausts. These catalysts, which typically operate with an air-to-fuel ratio $(\mathrm{A} / \mathrm{F})$ close to the stoichiometry [1,5-7], are generally made up of a quite complicated combination of noble metals supported on an oxide carrier. These noble metals have shown to dissociate readily NO when present in their fully reduced state $[1,2,4,8-10]$.

In addition to the ever more restricting limitations on carbon monoxide and nitrogen oxides, new regulations have appeared concerning the emission of carbon dioxide which is well known to be one of the greenhouse gases responsible for global warming. From this point of view, diesel engines, which operate typically under a lean mixture (air-to-fuel ratio (A/F) greater than unity), is among the solutions that must be considered to meet the $\mathrm{CO}_{2}$ emission requirements. Indeed, such burning conditions lead to a lowering of fuel consumption and consequently to a decrease of the $\mathrm{CO}_{2}$ emissions. Although these lean conditions have solved essentially the carbon monoxide and unburned hydrocarbon emission problems, they have made the classic TWC ineffective in removing nitrogen oxides from lean automotive gas exhausts. 
The catalytic solution using a traditional TWC associated with a storage component

2 (barium carbonate: $\mathrm{BaCO}_{3}$ ) [11] which has been adopted for lean gasoline engines has still to

3 be adapted for diesel cars which, as yet, have no suitable catalytic solution. A more attractive

4 alternative would be to develop a specific catalyst capable of reducing nitrogen oxide

5 emissions under lean conditions.

Among all the different formulations evaluated, to date, zeolite-based catalysts are probably those which have been studied most $[3,4]$. This might be due to the promising findings of Iwamoto et al. [12,13] and Lee and Armor [14] who showed that Cu-exchanged ZSM5 is able to decompose nitrogen monoxide at RT. This decomposition process is, however, self-inhibiting since as soon as nitrogen monoxide is decomposed on the catalytic sites (copper ions) they are poisoned by the oxygen left from nitrogen monoxide decomposition and, thus, the reaction stops. It is important to notice the striking similarity with model TWC reported in the case of stoichiometric mixture by Djéga-Mariadassou and co-workers $[7,15,16]$. These authors demonstrated the competition between the CO oxidation reaction and the assisted decomposition of NO by CO. In lean exhausts, carbon monoxide cannot be further used to assist the decomposition of nitrogen monoxide [16]. Consequently, other reductants such as hydrocarbons must be used to assist the decomposition of nitrogen monoxide. In the case of model exhausts, it has been shown by Matsumoto et al. [17] that alkenes, and more particularly propene, are the most efficient reductants to assist the nitrogen monoxide reduction. Alkenes are, however, also known as coke precursors for acidic catalysts which accounts for the dramatic deactivation of zeolite-based catalysts when propene is present in the lean mixture [18]. In addition to this coking phenomenon, zeolite-based catalysts are rather sensitive to water, and deactivation was also reported due to their low hydrothermal resistance [4]. These drawbacks have led researchers to focus on oxidessupported Platinum Group Metals (PGMs) catalysts. Due to their intrinsic higher activity [19- 
1 21], supported Pt catalysts have been the subject of the greatest number of studies [9,22-33].

2 These are followed by supported $\mathrm{Rh}[10,19-21,33]$ and $\mathrm{Pd}[19-21,33,34]$ catalysts. Although

3 these catalysts exhibit significant lean deNO $\mathrm{x}_{\mathrm{x}}$ activity with $\mathrm{C}_{3} \mathrm{H}_{6}$ as reductant and quite

4 reasonable stability, they have a rather narrow temperature operating window [19] and fairly

5 poor selectivity to $\mathrm{N}_{2}[9,30,34,35] . \mathrm{N}_{2} \mathrm{O}$, which is well known as a component of the

6 greenhouse effect [36], is, indeed, formed in substantial amounts. High selectivity to $\mathrm{N}_{2}$ has,

7 however, been reported for $\mathrm{Rh} / \mathrm{Al}_{2} \mathrm{O}_{3}$ catalysts $[10,19,33]$. Alumina-supported $\mathrm{Rh}$ catalysts usually operate at much higher temperatures than either supported Pt or Pd catalysts. This peculiarity led Obuchi et al. to the conclusion that this high selectivity to $\mathrm{N}_{2}$ was attributable to an additional catalytic effect of the alumina support [33]. The influence of the nature of the support was also investigated [19,20,30]. These studies, however, did not report on PGMs supported on ceria-zirconia $(\mathrm{CZ})$ until recently for $\mathrm{Rh} / \mathrm{CZ}$ [37] or Pt catalysts supported on $\mathrm{CZ}-\mathrm{Al}_{2} \mathrm{O}_{3}[31]$ and pure $\mathrm{CZ}[32]$. Finally, $\mathrm{CZ}$ showed only very moderate lean deNO $\mathrm{O}_{\mathrm{x}}$ activity in the presence of $\mathrm{C}_{3} \mathrm{H}_{6}[38]$.

The aim of this work is to investigate the influence of $\mathrm{Pd}$ addition to a chlorinated ceria-zirconia support on lean deNO $\mathrm{x}_{\mathrm{x}}$ with $\mathrm{C}_{3} \mathrm{H}_{6}$ as reductant. To our knowledge, such catalysts have not been investigated for this particular reaction. They have, however, been widely studied in the fields of TWC [39-43], $\mathrm{CH}_{4}$ total oxidation [44,45] and hydrocarbon reforming [46]. For comparison, the performances of a $\mathrm{Pd} / \mathrm{SiO}_{2}$ catalyst are also reported. $\mathrm{Pd} / \mathrm{CZ}$ catalysts show enhanced lean deNO $\mathrm{x}_{\mathrm{x}}$ activity and much higher $\mathrm{N}_{2}$ selectivity compared to $\mathrm{Pd} / \mathrm{SiO}_{2}$. This suggests the involvement of distinct lean deNO $\mathrm{x}_{\mathrm{x}}$ reaction mechanisms within these two catalytic systems. Based on transient and steady-state experiments, a mechanism of the lean $\mathrm{deNO}_{\mathrm{x}}$ is proposed for the $\mathrm{Pd} / \mathrm{CZ}$ catalysts. 


\section{Experimental}

2

\subsection{Catalyst synthesis} $120^{\circ} \mathrm{C}$ for 3 hours.

\subsection{2. $\mathrm{Pd} / \mathrm{CZ}$}

\subsection{3. $\mathrm{Pd} / \mathrm{SiO}_{2}$} reaction.

\subsubsection{Ceria-zirconia $\left(\mathrm{Ce}_{0.68} \mathrm{Zr}_{0.32} \mathrm{O}_{2}: \mathrm{CZ}\right)$}

The CZ solid solution was provided by Rhodia. The CZ was added to chloridric acid solution ( $\mathrm{pH}$ 1.9) prepared by adding $\mathrm{HCl}$ to distilled water. After ageing for 2 hours under vigorous stirring, $\mathrm{CZ}$ was filtered and washed with distilled water before being dried in air at

Two ceria-zirconia-supported Pd catalysts $(0.54$ and 0.89 wt\% Pd) were prepared by incipient wetness impregnation of the chlorinated support by an aqueous solution of $\mathrm{PdCl}_{2}$, $3 \mathrm{H}_{2} \mathrm{O}$ (Johnson Matthey). After impregnation, the catalysts were aged for 2 hours and dried in air at $120^{\circ} \mathrm{C}$ for three hours.

For comparison with $\mathrm{Pd} / \mathrm{CZ}$ catalysts, a silica (Degussa, Aerosil 50)-supported palladium catalyst $(0.93 \mathrm{wt} \% \mathrm{Pd})$ was prepared by incipient wetness impregnation of the support by an aqueous solution of $\mathrm{PdCl}_{2}, 3 \mathrm{H}_{2} \mathrm{O}$ (Johnson Matthey). After impregnation, the catalyst was aged for 2 hours and dried in air at $120^{\circ} \mathrm{C}$ for three hours.

\subsection{Catalyst characterization}

Metal and chlorine contents were determined by chemical analyses (CNRS Vernaison). The chlorine content was about $1 \mathrm{wt} \%$ for the CZ-based catalysts before and after 
The specific surface areas were determined by physisorption of $\mathrm{N}_{2}$ at $77 \mathrm{~K}$ using a

2 Quantasorb Jr. dynamic system equipped with a thermal conductivity detector (TCD). The 3 specific surface areas were calculated using the BET method. For CZ-supported catalysts, the

4 specific surface areas were about $100 \mathrm{~m}^{2} \mathrm{~g}^{-1}$ before and after testing, whereas that of $\mathrm{Pd} / \mathrm{SiO}_{2}$ 5 was about $50 \mathrm{~m}^{2} \mathrm{~g}^{-1}$.

\subsubsection{Determination of the percentage of exposed zero-valent $P d$ atom $\left(P E M^{0}\right)$}

With the well-known reducibility of the CZ support [47], the determination of the percentage of exposed zero-valent $\mathrm{Pd}$ atom was done by means of propene hydrogenation [48].

Prior to propene hydrogenation, the catalyst sample (30-60 mg deposited on sintered glass of a pyrex reactor) was heated in flowing $\mathrm{H}_{2}\left(100 \mathrm{~mL}_{\mathrm{NTP}} \mathrm{min}^{-1}\right)$ at atmospheric pressure with a heating rate of $3{ }^{\circ} \mathrm{C} \min ^{-1}$ up to $300^{\circ} \mathrm{C}$ and was kept at this temperature for $2 \mathrm{~h}$. After cooling to $-78^{\circ} \mathrm{C}$ under $\mathrm{H}_{2}$, the reaction was started. The partial pressure of propene was 51.8 torr, and the total flow rate was $107 \mathrm{~mL}_{\mathrm{NTP}} \mathrm{min}^{-1}$ with $\mathrm{H}_{2}$ as balance.

The composition of the effluents was analyzed by means of an on-line gas chromatograph (Hewlett Packard 5890, FID) equipped with a $\mathrm{CP}-\mathrm{Al}_{2} \mathrm{O}_{3} / \mathrm{KCl}$ (Chrompack, $50 \mathrm{~m}$ long, $0.32 \mathrm{~mm}$ inner diameter, $5 \mu \mathrm{m}$ film thickness) capillary column. The only detected product was propane.

From the initial reaction rates obtained, the numbers of exposed zero-valent $\mathrm{Pd}$ atoms were calculated according to a turnover rate of $0.40 \mathrm{~s}^{-1}$ for the propene hydrogenation reaction at $-78^{\circ} \mathrm{C}[48]$. 


\subsubsection{Temperature-Programmed Reduction}

Temperature-Programmed Reduction (TPR) experiments were performed in a conventional system equipped with a thermal conductivity detector. After calcination at $500^{\circ} \mathrm{C}$ for $2 \mathrm{~h}$, the reduction was carried out in a flow of $\mathrm{H}_{2}(5 \%)$ in $\mathrm{Ar}\left(25 \mathrm{~mL} \mathrm{~min}^{-1}\right)$ using a heating rate of $5^{\circ} \mathrm{C} \mathrm{min}^{-1}$. Typically, the reduction was carried out up to $700^{\circ} \mathrm{C}$ and then the sample (0.02-0.05 g) was kept at this temperature for $15 \mathrm{~min} . \mathrm{H}_{2} \mathrm{O}$ evolving in the course of the TPR experiments was trapped by a 5A molecular sieve. The amount of $\mathrm{H}_{2}$ uptake in the TPR was estimated from integrated peak areas.

\subsubsection{X-Ray diffraction}

X-Ray diffraction (XRD) patterns of $\mathrm{CZ}, \mathrm{SiO}_{2}, \mathrm{Pd}(0.93) / \mathrm{SiO}_{2}$ and $\mathrm{Pd} / \mathrm{CZ}$ were obtained on a SIEMENS D500 diffractometer with a $\mathrm{Cu} \mathrm{K}_{\alpha}$ monochromatized radiation.

\subsubsection{X-ray absorption near edge spectroscopy (XANES)}

X-Ray absorption measurements were carried out using synchrotron radiation of the XAS13 station at LURE (Orsay, France) on line D42 (May 3-4, 2001). Fluorescence yield spectra of $\mathrm{Pd}(0.54) / \mathrm{CZ}$ were recorded at RT using a Ge solid detector (Eurisys, 7 elements) combined with a multichannel analyser to select the Pd Ka fluorescence, whereas those of the reference compounds (Pd foils, $20 \mu \mathrm{m}$ thick, $\mathrm{PdO}$ (> 99\% pure, Lancaster)) were collected in the transmission mode. The incident beam was monochromatized using a Ge (400) double monochromator. XANES spectra were collected at the Pd K edge with a sampling step of 2.0 $\mathrm{eV} /$ point from 24300 to $24500 \mathrm{eV}$ and an integration time of $10 \mathrm{~s}$ and $2 \mathrm{~s}$ in fluorescence and transmission modes, respectively. The energy was calibrated using the Pd foil. XANES spectra were obtained from $\mathrm{Pd}(0.54) / \mathrm{CZ}$ either after oxidation or reduction treatments under flowing air or $\mathrm{H}_{2}\left(100 \mathrm{~mL}_{\mathrm{NTP}} \min ^{-1}\right)$ for $2 \mathrm{~h}$ at $500^{\circ} \mathrm{C}$. To avoid the exposure of the reduced 
1 sample to $\mathrm{O}_{2}$, the catalyst was then transferred into a UV cell (Suprasil quartz, $5 \mathrm{~cm}$ long, $1 \mathrm{~cm}$

2 wide and $1 \mathrm{~cm}$ high) that was finally sealed under vacuum $\left(5 \times 10^{-5}\right.$ torr $)$. In the case of the

3 oxidized sample, we checked that the high purity silica glass did not interfere with incident

4 and fluorescent beams. Superimposed spectra were, indeed, obtained with this sample located

5 either into the UV cell or between Kapton tapes. The cell was set to $45^{\circ}$ with respect to the

6 incident RX beam and the fluorescence detector. The extraction of the data was done with

7 Michalowicz's software package [49,50].

\subsubsection{Fourrier transform infra-red spectroscopy}

Fourrier transform infra-red (FTIR) spectra of adsorbed CO on $\mathrm{CZ}$ and $\mathrm{Pd}(0.89) / \mathrm{CZ}$

were collected on a Bruker Vector 22 FTIR spectrometer equipped with a liquid $\mathrm{N}_{2}$-cooled MCT detector and a data acquisition station. 256 scans were averaged with a spectral resolution of $2 \mathrm{~cm}^{-1}$.

The samples were pressed into self-supporting wafers of $6-11 \mathrm{mg} \mathrm{cm}^{-2}$. The wafers were loaded in a moveable glass sample holder, equipped on top with an iron magnet, inserted in a conventional pyrex-glass cell $\left(\mathrm{CaF}_{2}\right.$ windows $)$ connected to a vacuum system. The iron magnet allowed the transfer of the catalyst sample from the oven-heated region to the infrared light beam.

Prior to adsorption of $\mathrm{CO}$, the catalysts were submitted to a dynamic $\left(50 \mathrm{~cm}^{3} \mathrm{~min}^{-1}\right)$ reducing pretreatment $\left(5 \% \mathrm{H}_{2}\right.$ in $\mathrm{Ar}$, Air Liquide, $\left.99.999 \%\right)$ at $500^{\circ} \mathrm{C}$ for $2 \mathrm{~h}$ at atmospheric pressure. The catalyst samples were then evacuated $\left(10^{-6} \mathrm{mbar}\right)$ at $500^{\circ} \mathrm{C}$ for $60 \mathrm{~min}$ before the temperature was decreased to RT under dynamic vacuum.

CO (Air Liquide, 99.999\%), trapped at $77 \mathrm{~K}$, was adsorbed at RT at equilibrated pressures of 0.9 and 18 torr. 
The spectrum of the pretreated catalyst was used as reference and subtracted from the

2 spectra of the catalyst exposed to CO.

\subsection{Catalytic runs}

Prior to catalytic runs, the samples were calcined in situ in dry air at $500^{\circ} \mathrm{C}$

$\left(4^{\circ} \mathrm{C} \cdot \mathrm{min}^{-1}\right)$ for 2 hours with a flow rate of $500 \mathrm{~mL}_{\mathrm{NTP}} \min ^{-1}$ per gram of catalyst. Steady-state, Temperature-Programmed Desorption (TPD) and TemperatureProgrammed Surface Reaction (TPSR) experiments and were carried out. After being contacted with the appropriate gas mixture at RT, temperature transient experiments were carried out from RT to $500^{\circ} \mathrm{C}$ with a heating rate of $10^{\circ} \mathrm{C} \mathrm{min}^{-1}$. Before the TPD experiments, 11 the catalyst samples were flushed in $\mathrm{N}_{2}$ to remove RT physisorbed species from the adsorption mixture.

The experiments were carried out in a U-type quartz reactor. The sample $(0.2 \mathrm{~g}$ unless otherwise specified) was held between plugs of quartz wool, and the temperature was controlled through a WEST 4000 temperature controller using a $\mathrm{K}$ type thermocouple. Reactant gases were fed from independent mass flow controllers (Brooks 5850E). The total 17 flow was $250 \mathrm{~mL}_{\mathrm{NTP}} \mathrm{min}^{-1}$ to which corresponds a HSV (Hour Space Velocity) of $18112,500 \mathrm{~h}^{-1}$.

Catalytic experiments were carried out with $\mathrm{C}_{3} \mathrm{H}_{6}$ as reductant. Typically, the composition of the $\mathrm{C}_{3} \mathrm{H}_{6}-\mathrm{NO}-\mathrm{O}_{2}$ reacting mixture was: 1900 ppm $\mathrm{C}_{3} \mathrm{H}_{6}, 340$ ppm NO and 8\% $21 \mathrm{O}_{2}$ in $\mathrm{N}_{2}$. The reactants, diluted in $\mathrm{N}_{2}$, were fed from independent gas cylinders (Air Liquide). The reactor outflow was continuously analysed using the combination of four different detectors. An Eco Physics CLD 700 AL chemiluminescence $\mathrm{NO}_{\mathrm{x}}$ analyser (for $\mathrm{NO}$ and total $\mathrm{NO}_{\mathrm{x}}\left(\right.$ i.e. $\left.\mathrm{NO}+\mathrm{NO}_{2}\right)$ ) allowed the simultaneous detection of both $\mathrm{NO}$ and $\mathrm{NO}_{\mathrm{x}}$. Two Ultramat 6 IR analysers were used to monitor $\mathrm{N}_{2} \mathrm{O}, \mathrm{CO}$ and $\mathrm{CO}_{2}$. A FID detector (Fidamat 5A) was 
1 used to follow the concentration of hydrocarbons. We checked that, under our experimental

2 conditions, $\mathrm{CO}$ and $\mathrm{CO}_{2}$ had a negligible response on the $\mathrm{N}_{2} \mathrm{O}$ IR analyser, whereas that of

$3 \quad \mathrm{C}_{3} \mathrm{H}_{6}$ was significant. $\mathrm{C}_{3} \mathrm{H}_{6}$ contribution to the $\mathrm{N}_{2} \mathrm{O}$ signal was taken into account to calculate

4 the "true" $\mathrm{N}_{2} \mathrm{O}$ concentration $\left(\left[\mathrm{N}_{2} \mathrm{O}\right]\right)$ as follows (Eq. 1):

$$
\left[\mathrm{N}_{2} \mathrm{O}\right]=\left[\mathrm{N}_{2} \mathrm{O}\right]_{\text {meas. }}-\frac{\left.\left[\mathrm{N}_{2} \mathrm{O}\right]^{0} \times \mathrm{C}_{3} \mathrm{H}_{6}\right]_{\text {meas. }}}{\left[\mathrm{C}_{3} \mathrm{H}_{6}\right]_{\text {inlet }}}
$$

6 where $\left[\mathrm{N}_{2} \mathrm{O}\right]^{0},\left[\mathrm{C}_{3} \mathrm{H}_{6}\right]_{\text {inlet }},\left[\mathrm{C}_{3} \mathrm{H}_{6}\right]_{\text {meas. }}$ and $\left[\mathrm{N}_{2} \mathrm{O}\right]_{\text {meas. }}$ are: the concentrations of $\mathrm{N}_{2} \mathrm{O}$ due to the

7 contribution of the inlet concentration of $\mathrm{C}_{3} \mathrm{H}_{6}$, the inlet concentration of $\mathrm{C}_{3} \mathrm{H}_{6}, \mathrm{C}_{3} \mathrm{H}_{6}$ and $\mathrm{N}_{2} \mathrm{O}$

8 concentrations measured in the course of the reaction, respectively. As $\mathrm{N}_{2}$ was used as

9 balance, the conversion of $\mathrm{NO}_{\mathrm{x}}$ to $\mathrm{N}_{2}$ was calculated assuming $100 \%$ nitrogen mass balance

10 (Eq. 2):

$$
\text { Conversion of } \mathrm{NO}_{\mathrm{x}} \text { to } \mathrm{N}_{2}(\%)=\frac{\left[\mathrm{NO}_{\mathrm{x}}\right]_{\text {inlet }}-\left(\left[\mathrm{NO}_{\mathrm{x}}\right]_{\text {outlet }}+2 x\left[\mathrm{~N}_{2} \mathrm{O}\right]\right)}{\left[\mathrm{NO}_{\mathrm{x}}\right]_{\text {inlet }}}
$$

where $\left[\mathrm{NO}_{\mathrm{x}}\right]_{\text {inlet }}$ and $\left[\mathrm{NO}_{\mathrm{x}}\right]_{\text {outlet }}$ are the concentrations of $\mathrm{NO}_{\mathrm{x}}$ at the inlet and at the outlet of the reactor, respectively.

In one experiment, over $\mathrm{Ce}_{0.68} \mathrm{Zr}_{0.32} \mathrm{O}_{2}$, propene was substituted by 1-propanol (Merck, spectroscopic grade) with a concentration of 2200 ppm by means of a saturator.

\section{Results}

\subsection{Catalyst characterization}

\subsubsection{Determination of the percentage of exposed zero-valent metal atoms $\left(P E M^{0}\right)$}

Table 1 lists the percentage of exposed zero-valent palladium atoms of the CZabout 17 and $22 \%$ for $\mathrm{Pd} / \mathrm{CZ}$ and $\mathrm{Pd}(0.93) / \mathrm{SiO}_{2}$, respectively. 


\subsubsection{TPR results}

Fig. 1 shows the TPR profiles of the calcined catalysts. For $\mathrm{Pd}(0.93) / \mathrm{SiO}_{2}$, the trace of which is magnified by a factor of 4 for the sake of clarity, a reduction peak is observed at about $50^{\circ} \mathrm{C}$.

For the $\mathrm{CZ}$ sample, the trace of which is magnified by a factor of 3 , a broad reduction peak starting around $400^{\circ} \mathrm{C}$ and ranging to a maximum at $530^{\circ} \mathrm{C}$ is observed. This reduction temperature region corresponds well with that reported for various ceria-zirconia materials [51-55].

The presence of noble metal on CZ modifies substantially the features of the TPD profiles. Indeed, the reduction peak revealed over the $\mathrm{CZ}$ sample vanishes, while a strong signal appears at temperatures below $200^{\circ} \mathrm{C}$ depending on the catalyst sample. It is observed that the reduction peak shifts to lower temperature with increasing Pd content. Luo and Zheng [56] reported a similar feature despite the fact that their TPR traces were substantially different from ours.

As it is well established that the incorporation of noble metals increases the reducibility of the ceria-related materials $[47,51,52,56,57]$, quantitative analysis of the TPR traces is not discussed. Overall, the amount of $\mathrm{H}_{2}$ consumed in the course of the TPR was close to $0.510^{-3} \mathrm{~mol} \mathrm{~g}^{-1}$ for all samples. This value agrees well with those listed by Luo and Zheng for $\mathrm{Ce}_{0.5} \mathrm{Zr}_{0.5} \mathrm{O}_{2}$-supported Pd catalysts [56].

Finally, the comparison of the TPR traces of $\mathrm{Pd}(0.93) / \mathrm{SiO}_{2}$ and $\mathrm{Pd}(0.89) / \mathrm{CZ}$ clearly shows that the $\mathrm{Pd}$ species interact to a greater extent with $\mathrm{CZ}$ than with $\mathrm{SiO}_{2}$. The reduction peak of these Pd species supported on $\mathrm{CZ}$ is, indeed, shifted to higher temperature compared with that of $\mathrm{Pd}(0.93) / \mathrm{SiO}_{2}$. 
XRD patterns of the calcined $\mathrm{SiO}_{2}, \mathrm{Pd}(0.93) / \mathrm{SiO}_{2}$ and $\mathrm{CZ}$ samples are shown in Fig. 2. After calcination of $\mathrm{Pd}(0.93) / \mathrm{SiO}_{2}$, a diffraction peak is observed at about $33.8^{\circ}$ which corresponds to $\mathrm{PdO}$ (101 plane). Two very weak peaks at about 41.9 and $54.8^{\circ}$ can also be assigned to PdO. As shown in Fig. 2, the diffraction pattern of $\mathrm{CZ}$ exhibits 4 peaks at about $29,33.8,48.3$ and $57.2^{\circ}$. Owing to the weak intensity of the PdO peaks and the overlapping with $\mathrm{CZ}$ support, the presence of $\mathrm{PdO}$ on the $\mathrm{CZ}$-supported catalysts could not be established through XRD.

\subsubsection{XANES measurements}

XANES spectra of the $\operatorname{Pd}(0.54)$ catalyst after calcination or reduction are shown in Fig. 3. The shape of the XANES spectra of the $\mathrm{Pd}(0.54) / \mathrm{CZ}$ sample either calcined (----) or reduced (-) corresponds fairly well to that of the $\mathrm{PdO}(\mathbf{\Delta})$ and $\mathrm{Pd}$ metal $(\Delta)$ references (Fig. 3), respectively. This result markedly differs from that of the reduced $\mathrm{Rh} / \mathrm{CZ}$ catalyst, which showed a XANES spectrum different from both $\mathrm{Rh}$ foil and $\mathrm{Rh}_{2} \mathrm{O}_{3}$ references [58].

The CO-FTIR technique was used to probe the nature of the metal species [59] supported on CZ.

The FTIR spectra of adsorbed CO under equilibrated pressures of 0.9 and 18 torr of $21 \mathrm{CO}$ are shown in Fig. 4 for $\mathrm{CZ}$ and $\mathrm{Pd}(0.89) / \mathrm{CZ}$. It is worthwhile noting the fairly low intensity of the $\mathrm{CO}$ absorption bands. This is why the CO-FTIR of the $\mathrm{Pd}(0.54) / \mathrm{CZ}$ catalyst was not investigated.

Over CZ (Fig. 4a), two CO absorption bands are observed at 1575 and $2167 \mathrm{~cm}^{-1}$. The band at $1575 \mathrm{~cm}^{-1}$ can be assigned to the formation of carbonates [60]. This band appears as 
1 soon as the equilibrated pressure of $\mathrm{CO}$ is $0.9 \mathrm{torr}$, whereas the band at $2167 \mathrm{~cm}^{-1}$ is observed

2 only at a pressure of 18 torr. This latter band has been attributed to the weak interaction of CO 3 with Ce surface sites [61-64].

The FTIR spectra of adsorbed $\mathrm{CO}$ on $\mathrm{Pd}(0.89) / \mathrm{CZ}$ (Fig. 4b) differ markedly from those of CZ. The formation of carbonate is not observed, and a rather broad absorption band

6 from 1850 to $2090 \mathrm{~cm}^{-1}$ is revealed, with two maxima at 1950 and $2083 \mathrm{~cm}^{-1}$. The band at $71950 \mathrm{~cm}^{-1}$, also found in a previous work of Badri et al. on a chlorinated $\mathrm{Pd} / \mathrm{CeO}_{2}$ sample 8 [61], can be assigned to bridged $\mathrm{CO}$ species bonded to zero-valent $\mathrm{Pd}$ atoms $\left(\mathrm{Pd}_{2}^{0} \mathrm{CO}\right)$ $9 \quad[43,65,66]$. In contrast, the band with the maximum at $2083 \mathrm{~cm}^{-1}$ corresponds to CO species singly bonded to $\mathrm{Pd}^{0}$ atoms $[43,59,61,63,65]$. $\mathrm{CO}$ coordinated to $\mathrm{Ce}^{\mathrm{z+}}$ centers, acting as Lewis acid sites, gives rise to an absorption band at $2175 \mathrm{~cm}^{-1}$, as already reported by Badri et al. [61].

\subsubsection{NO oxidation}

As reported earlier [38 and references therein], the oxidation of $\mathrm{NO}$ to $\mathrm{NO}_{2}$ is suspected to be an essential step of the deNO $\mathrm{N}_{\mathrm{x}}$ process. This reaction was, thus, investigated over $\mathrm{CZ}$ and $\mathrm{Pd}(0.54) / \mathrm{CZ}$ under steady-state conditions. As shown in Fig. 5, NO oxidation is the greatest at $400^{\circ} \mathrm{C}$. At higher temperatures, the conversion of $\mathrm{NO}$ decreases due to thermodynamic limitations. It is important to note that the addition of Pd does not promote NO oxidation, and this reaction is only catalysed by the CZ support.

\subsubsection{Adsorption of $\mathrm{NO}-\mathrm{O}_{2}-\mathrm{TPD}$ in $\mathrm{N}_{2}$}

Fig. 6 shows the $\mathrm{NO}_{\mathrm{x}}$ TPD profiles in $\mathrm{N}_{2}$ of samples contacted with $\mathrm{NO}-\mathrm{O}_{2}$ (340 ppm8\%). The addition of Pd to CZ does not affect the TPD profiles to a large extent. In both cases, two NO peaks are observed at about 100 and $420^{\circ} \mathrm{C}$, and a broad $\mathrm{NO}_{2}$ desorption 
1 profile is seen from 50 to $450^{\circ} \mathrm{C}$. This $\mathrm{NO}_{2}$ feature exhibits two maxima at low and high

2 temperatures. The high temperature maximum is close to $350^{\circ} \mathrm{C}$ and is not affected by the

3 introduction of $\mathrm{Pd}$. In contrast, the low temperature maximum shifts from 116 to $136^{\circ} \mathrm{C}$ when

$4 \mathrm{Pd}$ is added to $\mathrm{CZ}$ (Fig. 6c). For both samples, the quantities of adsorbed and desorbed $\mathrm{NO}_{\mathrm{x}}$

5 closely match (Table 2). Table 2 shows that the amount of adsorbed $\mathrm{NO}_{\mathrm{x}}$ fluctuates to some

6 extent. This was related to slightly different times of exposure and not to differences in the

7 starting conditions of the samples. In agreement with previous work [67], $\mathrm{PdO} / \mathrm{SiO}_{2}$ did not 8 chemisorb $\mathrm{NO}_{\mathrm{x}}$. Consequently, the TPD in $\mathrm{C}_{3} \mathrm{H}_{6}-\mathrm{O}_{2}$ after $\mathrm{NO}_{\mathrm{x}}$ chemisorption was not 9 performed.

3.1.8. Adsorption of $\mathrm{NO}-\mathrm{O}_{2}-\mathrm{TPD}$ in $\mathrm{C}_{3} \mathrm{H}_{6}-\mathrm{O}_{2}$ After exposure of the samples to a NO- $\mathrm{O}_{2}$ mixture, the TPD profiles obtained in $\mathrm{C}_{3} \mathrm{H}_{6^{-}}$ $\mathrm{O}_{2}$ are shown in Fig. 7 for $\mathrm{CZ}$ and $\mathrm{Pd}(0.89) / C Z$. Before TPD, the samples were flushed by $\mathrm{N}_{2}$ to remove physisorbed $\mathrm{NO}_{\mathrm{x}}$ and then contacted with the desorption gas mixture $\left(\mathrm{C}_{3} \mathrm{H}_{6}-\mathrm{O}_{2}\right)$ for a few minutes at RT. For both samples, a $\mathrm{C}_{3} \mathrm{H}_{6}$ desorption profile is observed at low temperature. It is worth mentioning that in the case of the oxidation of $\mathrm{C}_{3} \mathrm{H}_{6}$ by $\mathrm{O}_{2}$ without pre-adsorption of $\mathrm{NO}_{\mathrm{x}}$ (not shown), a similar desorption feature was observed. This low temperature desorption feature is, thus, attributed to propene species chemisorbed on catalytic sites different from those occupied by adsorbed $\mathrm{NO}_{\mathrm{x}}$ species. For both catalysts, $\mathrm{HC}$ consumption starts at $80^{\circ} \mathrm{C}$ and a more drastic $\mathrm{HC}$ consumption is observed at about $110^{\circ} \mathrm{C}$. It 21 is worthwhile mentioning that the $\mathrm{HC}$ consumption profile is slightly different for $22 \mathrm{Pd}(0.89) / \mathrm{CZ}$ compared with that of $\mathrm{CZ}$. At temperatures higher than $150^{\circ} \mathrm{C}$, the $\mathrm{HC}$ concentration reaches its input concentration for $\mathrm{CZ}$ (Fig. 7a). This phenomenon, however, is not observed for $\mathrm{Pd}(0.89) / \mathrm{CZ}$ (Fig. 7b). The first column of Table 3 shows that the light-off 
1 temperature of $\mathrm{C}_{3} \mathrm{H}_{6}$ in the course of the TPD in $\mathrm{C}_{3} \mathrm{H}_{6}-\mathrm{O}_{2}$ decreases drastically with the 2 addition of $\mathrm{Pd}$.

Considering desorption of the $\mathrm{N}_{t} \mathrm{O}_{\mathrm{x}}\left(\mathrm{NO}, \mathrm{NO}_{2}\right.$ and $\left.\mathrm{N}_{2} \mathrm{O}\right)$ species, rather complicated profiles are observed (Fig. 7). A detailed description of the traces seen for $\mathrm{CZ}$ is reported in a recent article [38]. The amounts of adsorbed and desorbed $\mathrm{N}_{t} \mathrm{O}_{\mathrm{x}}$ species are listed in Table 2 .

6 For both catalysts, a comparison of the desorbed quantities (Table 2) and profiles of $\mathrm{N}_{t} \mathrm{O}_{\mathrm{x}}$ 7 species of the two TPD experiments either in $\mathrm{N}_{2}$ (Fig. 6) or in $\mathrm{C}_{3} \mathrm{H}_{6}-\mathrm{O}_{2}$ (Fig. 7) after exposure of the samples to $\mathrm{NO}-\mathrm{O}_{2}$ shows striking differences. First, NO becomes the major $\mathrm{N}_{t} \mathrm{O}_{\mathrm{x}}$ species of the TPD in $\mathrm{C}_{3} \mathrm{H}_{6}-\mathrm{O}_{2}$. In contrast, $\mathrm{NO}_{2}$ is the major species of the TPD in $\mathrm{N}_{2}$. Second, the global amount of desorbed $\mathrm{N}_{\mathrm{t}} \mathrm{O}_{\mathrm{x}}$ species, taking into account that $\mathrm{N}_{2} \mathrm{O}$ originates from the recombination of two $\mathrm{NO}_{\mathrm{x}}$ molecules, is always lower than that adsorbed for the TPD in $\mathrm{C}_{3} \mathrm{H}_{6}-\mathrm{O}_{2}$. On the other hand, adsorbed and desorbed $\mathrm{NO}_{\mathrm{x}}$ quantities agree well for the TPD in $\mathrm{N}_{2}$. These results suggest that part of the adsorbed $\mathrm{NO}_{\mathrm{x}}$ is reduced to $\mathrm{N}_{2}$ in the presence of $\mathrm{C}_{3} \mathrm{H}_{6}$ in the desorption mixture. Finally, the $\mathrm{N}_{t} \mathrm{O}_{x}$ TPD profiles (Fig. 7) suggest that part of the adsorbed $\mathrm{NO}_{\mathrm{x}}$ species reacted with $\mathrm{C}_{3} \mathrm{H}_{6}$ in the low temperature region (50$115^{\circ} \mathrm{C}$ ). For $\mathrm{N}_{\mathrm{t}} \mathrm{O}_{\mathrm{x}}$ species, the $\mathrm{NO}_{\mathrm{x}}$ desorption feature is clearly truncated in this low temperature region compared to that of the TPD in $\mathrm{N}_{2}$ (Fig. 6). As already discussed [38], these concomitant consumptions suggest the interaction of adsorbed $\mathrm{NO}_{\mathrm{x}}$ species $\left(\mathrm{ad}-\mathrm{NO}_{\mathrm{x}}\right)$ with propene and the formation of mixed compounds $\left(\mathrm{R}-\mathrm{NO}_{\mathrm{x}}\right)$ stored on the catalytic material. For $\mathrm{Pd}(0.89) / \mathrm{CZ}$, it is worth adding that a stabilised $\mathrm{HC}$ consumption occurs up to 21 higher temperatures, ca. $150^{\circ} \mathrm{C}$, compared with that observed on $\mathrm{CZ}$ (Fig. 7). Overall, the broad $\mathrm{N}_{\mathrm{t}} \mathrm{O}_{\mathrm{x}}$ desorption features observed at low temperatures $\left(100-200^{\circ} \mathrm{C}\right)$ over $\mathrm{CZ}$ become thinner over $\mathrm{Pd}(0.89) / \mathrm{CZ}$, whereas those at high temperatures $\left(220-400^{\circ} \mathrm{C}\right)$ are clearly shifted to lower temperatures $\left(200-300^{\circ} \mathrm{C}\right)$ with the incorporation of $\mathrm{Pd}$. In addition, the amount of 
$1 \mathrm{NO}_{2}$ desorbed at temperatures higher than $200^{\circ} \mathrm{C}$ is much lower over $\mathrm{Pd}(0.89) / \mathrm{CZ}$ than over

2 CZ. That of $\mathrm{N}_{2} \mathrm{O}$ is, however, greater.

3.1.9. $\mathrm{C}_{3} \mathrm{H}_{6}$ oxidation by $\mathrm{O}_{2}$

Fig. 8 shows that the $\mathrm{C}_{3} \mathrm{H}_{6}$ oxidation profiles are obviously different depending on the nature of the catalyst support.

On $\mathrm{Pd}(0.89) / \mathrm{CZ}, \mathrm{C}_{3} \mathrm{H}_{6}$ oxidation is rather similar to that observed after adsorption of NO-O $\mathrm{O}_{2}$ (Fig. 7b) with comparable light-off temperature (Table 3). On such a catalyst, however, the consumption of $\mathrm{C}_{3} \mathrm{H}_{6}$ in the $\mathrm{C}_{3} \mathrm{H}_{6}-\mathrm{O}_{2}$ reaction starts at a higher temperature and is more pronounced before $250^{\circ} \mathrm{C}$ than after adsorption of $\mathrm{NO}-\mathrm{O}_{2}$. In contrast, $\mathrm{C}_{3} \mathrm{H}_{6}$ oxidation proceeds much more steeply in a much narrower range of temperature (from 195 to $260^{\circ} \mathrm{C}$ ) on $\mathrm{Pd}(0.93) / \mathrm{SiO}_{2}$ than on $\mathrm{Pd}(0.89) / \mathrm{CZ}$ (Fig. 8). In addition, $\mathrm{C}_{3} \mathrm{H}_{6}$ does not chemisorb at $\mathrm{RT}$ on $\mathrm{Pd}(0.93) / \mathrm{SiO}_{2}$, as is the case of $\mathrm{Pd}(0.89) / \mathrm{CZ}$ that shows a low temperature $\mathrm{C}_{3} \mathrm{H}_{6}$ desorption feature. For $\mathrm{Pd}(0.93) / \mathrm{SiO}_{2}$, it is worthwhile noting that the experiment reported on Fig. 8 was carried out after a previous $\mathrm{C}_{3} \mathrm{H}_{6}-\mathrm{NO}-\mathrm{O}_{2}$ Temperature-Programmed Surface Reaction (TPSR). It will be shown later (please refer to part 3.1.10.) that for $\mathrm{Pd}(0.93) / \mathrm{SiO}_{2}$ such an experimental sequence does significantly influence the light-off temperature of $\mathrm{C}_{3} \mathrm{H}_{6}$, whereas it has no impact on CZ-supported catalysts.

Table 3 shows that the $\mathrm{C}_{3} \mathrm{H}_{6}$ light-off temperature for the $\mathrm{C}_{3} \mathrm{H}_{6}-\mathrm{O}_{2}$ reaction is the lowest for $\mathrm{Pd}(0.93) / \mathrm{SiO}_{2}$ and the highest for CZ. Finally, $\mathrm{Pd}$ promotes significantly $\mathrm{C}_{3} \mathrm{H}_{6}$ 21 oxidation for the CZ-based catalysts.

\subsubsection{0. $\mathrm{C}_{3} \mathrm{H}_{6}-\mathrm{NO}-\mathrm{O}_{2}$ TPSR experiment}

TPSR of the complete reacting mixture was performed after exposure of $\operatorname{Pd}(0.89) / C Z$

to the reacting mixture at RT (Fig. 9). The features observed are comparable to those seen for 
1 the TPD in $\mathrm{C}_{3} \mathrm{H}_{6}-\mathrm{O}_{2}$ after adsorption of $\mathrm{NO}-\mathrm{O}_{2}$ (Fig. 7b). NO desorption is the major $\mathrm{N}_{\mathrm{t}} \mathrm{O}_{\mathrm{x}}$

2 species with a two peak profile $\left(100\right.$ and $\left.220^{\circ} \mathrm{C}\right)$. The formation of $\mathrm{NO}_{2}$ and $\mathrm{N}_{2} \mathrm{O}$ are,

3 however, more limited than those obtained for the TPD experiment in $\mathrm{C}_{3} \mathrm{H}_{6}-\mathrm{O}_{2}$ (Fig. 7). $\mathrm{C}_{3} \mathrm{H}_{6}$

4 and $\mathrm{NO}_{\mathrm{x}}$ consumptions detected in the low temperature region in the case of the TPD

5 experiment in $\mathrm{C}_{3} \mathrm{H}_{6}-\mathrm{O}_{2}$ are no longer observed. $\mathrm{C}_{3} \mathrm{H}_{6}$ is moderately consumed from 100 to

$6200^{\circ} \mathrm{C}$ and at higher temperatures the oxidation of $\mathrm{C}_{3} \mathrm{H}_{6}$ accelerates. More interesting is that

7 the $\mathrm{NO}_{\mathrm{x}}$ profile shows a decrease of the $\mathrm{NO}_{\mathrm{x}}$ concentration at $297^{\circ} \mathrm{C}$ corresponding to $50 \%$ of

8 the $\mathrm{NO}_{\mathrm{x}}$ inlet concentration. At this temperature, the conversion of $\mathrm{C}_{3} \mathrm{H}_{6}$ is $79 \%$. At higher

9 temperatures, the $\mathrm{NO}_{\mathrm{x}}$ concentration reaches back its inlet concentration, and $\mathrm{NO}$ is oxidized to $\mathrm{NO}_{2}$ when full conversion of $\mathrm{C}_{3} \mathrm{H}_{6}$ is achieved at about $400^{\circ} \mathrm{C}$.

Compared with the TPSR profiles found on CZ (Fig. 12 of [38]), the desorption peak of $\mathrm{NO}$ reported in this experiment at about $300^{\circ} \mathrm{C}$ is no longer observed in the course of the TPSR on $\mathrm{Pd}(0.89) / \mathrm{CZ}$, as a $\mathrm{NO}_{\mathrm{x}}$ deficit occurs in this temperature range (Fig. 9). $500^{\circ} \mathrm{C}$ to $\mathrm{RT}$ (reverse TPSR) after the first TPSR experiment, the $\mathrm{C}_{3} \mathrm{H}_{6}$ light-off temperature and the selectivity to $\mathrm{N}_{2}$ are modified significantly. The $\mathrm{C}_{3} \mathrm{H}_{6}$ light-off temperature and the $\mathrm{N}_{2}$ selectivity of the TPSR and the reverse TPSR decrease from 298 to $237^{\circ} \mathrm{C}$ (Table 3) and from 70 to $30 \%$, respectively. On the other hand, the conversion of $\mathrm{NO}_{\mathrm{x}}$ to $\mathrm{N}_{2}$ remains almost constant and close to $9 \%$ at maximum $\mathrm{NO}_{\mathrm{x}}$ conversion.

21 Such phenomena were not observed for the CZ-based catalysts for which the $\mathrm{C}_{3} \mathrm{H}_{6}$ and $\mathrm{NO}_{\mathrm{x}}$ profiles of the TPSR and the reverse TPSR were comparable.

As in the case of the $\mathrm{C}_{3} \mathrm{H}_{6}-\mathrm{O}_{2}$ reaction, Table 3 shows that the $\mathrm{C}_{3} \mathrm{H}_{6}$ light-off temperature for the TPSR is lowest for $\mathrm{Pd}(0.93) / \mathrm{SiO}_{2}$ and highest for $\mathrm{CZ}$. Pd also promotes significantly $\mathrm{C}_{3} \mathrm{H}_{6}$ oxidation for the CZ-based catalysts. 


\subsubsection{Steady-state $\mathrm{NO}-\mathrm{C}_{3} \mathrm{H}_{6}-\mathrm{O}_{2}$ reaction}

Prior to steady-state measurements, the catalysts were submitted to a TPSR under the complete reacting mixture from $\mathrm{RT}$ to $500^{\circ} \mathrm{C}$ with a heating rate of $10^{\circ} \mathrm{C} \mathrm{min}^{-1}$.

Fig. 10 shows the performances of the catalysts for the reduction of $\mathrm{NO}_{\mathrm{x}}$ under steadystate conditions with stepwise increase of the temperature. The temperature of maximum of $\mathrm{N}_{2}$ formation, the corresponding $\mathrm{NO}_{\mathrm{x}}$ and $\mathrm{C}_{3} \mathrm{H}_{6}$ conversions are listed in Table 4.

It is obvious that the introduction of $\mathrm{Pd}$ leads to a significant increase of $\mathrm{NO}_{\mathrm{x}}$ reduction to $\mathrm{N}_{2}$ as well as a drastic decrease of the $\mathrm{C}_{3} \mathrm{H}_{6}$ light-off temperature. Table 3 lists the temperature of light-off of $\mathrm{C}_{3} \mathrm{H}_{6}$ over various $\mathrm{Pd}$-containing catalysts with respect to reaction conditions. From this table it can also be concluded that the presence of NO does not influence this light-off temperature, as was the case for CZ ([38] and first line of Table 3).

Conversion of $\mathrm{NO}_{\mathrm{x}}$ to $\mathrm{N}_{2}$ higher than $20 \%$ is obtained on the $\mathrm{Pd} / \mathrm{CZ}$ catalysts. On the other hand, $\mathrm{Pd}(0.93) / \mathrm{SiO}_{2}$ shows a rather low conversion of $\mathrm{NO}_{\mathrm{x}}$ to $\mathrm{N}_{2}$ close to that found for

$\mathrm{CZ}$, despite the fact that the light-off temperature of propene is similar to that of the most active CZ-based catalyst $(\operatorname{Pd}(0.89) / C Z)$. One also may note that propene oxidation is steeper over $\mathrm{Pd}(0.93) / \mathrm{SiO}_{2}$ than over $\mathrm{Pd} / \mathrm{CZ}$ catalysts. It is worthwhile noting that $\mathrm{N}_{2}$ selectivity is higher than $80 \%$ on CZ-based catalysts, whereas that of $\mathrm{Pd}(0.93) / \mathrm{SiO}_{2}$ is of $28 \%$ (Table 4 ). Finally, Fig. 10e shows that $\mathrm{NO}$ oxidation to $\mathrm{NO}_{2}$ is almost eliminated in the presence of $\mathrm{C}_{3} \mathrm{H}_{6}$ before $400^{\circ} \mathrm{C}$, the temperature of which corresponds to the almost complete conversion of $\mathrm{C}_{3} \mathrm{H}_{6}$ (Fig. 10c).

To illustrate the high stability of the CZ-supported catalysts, Table 5 reports on the influence of time on stream on the reduction of $\mathrm{NO}_{\mathrm{x}}$ on $\mathrm{Pd}(0.89) / \mathrm{CZ}$. This catalyst exhibits $\mathrm{NO}_{\mathrm{x}}$ conversion to $\mathrm{N}_{2}$ by about $30 \%$ and does not deactivate in the absence of water for $1 \mathrm{~h}$. After about 1 hour of run, $1.7 \%$ of water was introduced in the reaction mixture. This addition decreases the conversion of $\mathrm{NO}_{\mathrm{x}}$ by about $10 \%$. More interesting is that the catalyst does not 
1 deactivate over a period of 19 hours on stream in the presence of water. After 19 hours on

2 stream, the initial activity is restored when water is removed from the feed. This suggests that

$3 \quad \mathrm{H}_{2} \mathrm{O}$ competes with the active sites responsible for $\mathrm{N}_{2}$ formation. $\mathrm{C}_{3} \mathrm{H}_{6}$ conversion remains

4 almost unaffected and close to $60 \%$. Chemical analysis of this sample after reaction reveals a

5 carbon content of only $0.4 \mathrm{wt} \%$.

6

\subsubsection{Steady-state $\mathrm{NO}-\mathrm{C}_{3} \mathrm{H}_{6}-\mathrm{O}_{2}$ reaction over mechanical mixtures}

The results obtained over two mechanical mixtures of $\mathrm{Pd}(0.89) / \mathrm{CZ}+\mathrm{SiO}_{2}$ and

$\mathrm{Pd}(0.93) / \mathrm{SiO}_{2}+\mathrm{CZ}$ are shown in Fig. 11. It is obvious that the mechanical mixture of $\mathrm{Pd}(0.89) / \mathrm{CZ}+\mathrm{SiO}_{2}$ (Fig. 11a) is more active than its counterpart (Fig. 11b) over a wide range

11 of temperature. Table 6 compares the performances of the mechanical mixtures at about $250^{\circ} \mathrm{C}$. Given that $\mathrm{SiO}_{2}$ exhibits no deNO $\mathrm{N}_{\mathrm{x}}$, the activity reported for the mechanical mixture of $\mathrm{Pd}(0.89) / \mathrm{CZ}$ and $\mathrm{SiO}_{2}$ is only due to $\mathrm{Pd}(0.89) / \mathrm{CZ}$. It is quite unusual to note that the $\mathrm{HSV}$ does not influence the performance of the $\mathrm{Pd}(0.89) / \mathrm{CZ}$ catalyst as the experiments carried out with 0.10 or $0.20 \mathrm{~g}$ of this sample give comparable deNO $\mathrm{x}_{\mathrm{x}}$ activities (Table 4 and Table 6, Fig. 10d and Fig. 11a). This unexpected result suggests that the geometry of the reactor used in this study was not the best to achieve optimised deNO $\mathrm{x}_{\mathrm{x}}$ conversions. The deNO $\mathrm{x}_{\mathrm{x}}$ activity reported for the mechanical mixture made up of $\mathrm{Pd}(0.93) / \mathrm{SiO}_{2}$ and $\mathrm{CZ}$ roughly corresponds to the sum of the activities of both catalytic systems. These conclusions are corroborated by the selectivity to $\mathrm{N}_{2}$ that is: (i) close to that reported for $\mathrm{Pd}(0.89) / \mathrm{CZ}$ (Table 4 ) for the mechanical mixture made up of $\mathrm{Pd}(0.89) / \mathrm{CZ}$ and $\mathrm{SiO}_{2}$ (Table 6), and (ii) intermediate to those of $\mathrm{Pd}(0.93) / \mathrm{SiO}_{2}$ and $\mathrm{CZ}$ (Table 4) for the corresponding mechanical mixture (Table 6). 


\subsubsection{Steady-state $\mathrm{NO}-\mathrm{C}_{3} \mathrm{H}_{6} \mathrm{OH}-\mathrm{O}_{2}$ reaction over $\mathrm{Ce}_{0.68} \mathrm{Zr}_{0.32} \mathrm{O}_{2}$}

Over $\mathrm{CZ}, \mathrm{C}_{3} \mathrm{H}_{6}$ was substituted by $1-\mathrm{C}_{3} \mathrm{H}_{7} \mathrm{OH}$ as reductant. The results of this steadystate experiment are shown in Fig. 12. In contrast to the steady-state measurements with $\mathrm{C}_{3} \mathrm{H}_{6}$ as reductant (Fig. 10b), CZ exhibits a higher lean deNO $\mathrm{x}_{\mathrm{x}}$ activity in the presence of 1- $\mathrm{C}_{3} \mathrm{H}_{7} \mathrm{OH}$ over a broader range of temperatures than with $\mathrm{C}_{3} \mathrm{H}_{6}$. In comparison, the highest activity, $19 \% \mathrm{NO}_{\mathrm{x}}$ to $\mathrm{N}_{2}$ at $283^{\circ} \mathrm{C}$ when $1-\mathrm{C}_{3} \mathrm{H}_{7} \mathrm{OH}$ is used as reductant, is more than twice that listed at $361^{\circ} \mathrm{C}$ with $\mathrm{C}_{3} \mathrm{H}_{6}$ (Table 4). The selectivity to $\mathrm{N}_{2}$ in the presence of $\mathrm{C}_{3} \mathrm{H}_{7} \mathrm{OH}$ (76\%) is comparable to that found in the presence of $\mathrm{C}_{3} \mathrm{H}_{6}(81 \%)$.

\section{Discussion}

\subsection{State of Pd in the supported Pd catalysts}

The XRD pattern of the calcined $\mathrm{Pd}(0.93) / \mathrm{SiO}_{2}$ sample (Fig. 2) indicates, as expected, the presence of PdO. The corresponding reduced sample exhibits propene hydrogenation activity (Table 1).

As mentioned in the results (part 3.1.3.), due to the overlapping of the diffraction peaks of $\mathrm{PdO}$ with those of $\mathrm{CZ}, \mathrm{XRD}$ characterisation could not be successfully used to investigate the nature of the Pd species of the Pd/CZ catalysts. XANES measurements of oxidised and reduced $\mathrm{Pd}(0.54) / \mathrm{CZ}$ samples show that they closely resemble those of $\mathrm{PdO}$ and the Pd foil, respectively (Fig. 3). As in the case of $\mathrm{Pd} / \mathrm{SiO}_{2}$, these XANES measurements suggest that $\mathrm{Pd}$ is present as $\mathrm{PdO}$ for the calcined sample (Fig. 3a). $\mathrm{Pd} / \mathrm{CZ}$ catalysts also catalyse propene hydrogenation (Table 1), which agrees fairly well with the XANES measurements of the reduced $\mathrm{Pd}(0.54) / \mathrm{CZ}$ sample (Fig. 3), indicating the presence of reduced Pd clusters. Holles and Davis have reported, however, that $\mathrm{Pd}(4.0) / \mathrm{CeO}_{\mathrm{x}} / \mathrm{Al}_{2} \mathrm{O}_{3}$ could not be fully reduced even after exposure to $\mathrm{CO}$ at $400^{\circ} \mathrm{C}$ [68]. Comparable conclusions were also 
1 drawn by Matsumara and coworkers for $\mathrm{Pd}(3.0) / \mathrm{CeO}_{2}$ and $\mathrm{Pd}(2.0) / \mathrm{ZrO}_{2}$ samples reduced

2 under $\mathrm{H}_{2}$ at 300 and $400^{\circ} \mathrm{C}[69,70]$, respectively. As X-ray absorption spectroscopy is known

3 to provide an average picture of the targeted metal species [71], CO-FTIR measurements were

4 also performed on $\operatorname{Pd}(0.89) / C Z$ (Fig. 4b). In agreement with XANES measurements, CO-

5 FTIR spectra recorded after $\mathrm{H}_{2}$ reduction at $500^{\circ} \mathrm{C}$ do not reveal the presence of Pd oxidised

6 species, as is the case with a CZ-supported Rh catalyst [58].

The characterisation of these catalysts after oxidising or reducing pretreatments were motivated due to the initial calcination of the samples and the $\mathrm{C}_{3} \mathrm{H}_{6}-\mathrm{NO}-\mathrm{O}_{2}$ TPSR experiment that was carried out before steady-state measurements, the TPSR experiment leading to the exposure of the calcined sample to the $\mathrm{C}_{3} \mathrm{H}_{6}$ reductant. The characterisation of the $\mathrm{Pd} / \mathrm{CZ}$ catalysts indicates that $\mathrm{Pd}$ is present as $\mathrm{PdO}$ in the calcined samples. Nevertheless, one might wonder about the nature of the $\mathrm{Pd}$ species in the course of the lean $\mathrm{NO}_{\mathrm{x}}$ reaction. FernàndezGarcia et al. have recently shown that even under a stoichiometric $\mathrm{C}_{3} \mathrm{H}_{6}+\mathrm{CO}+\mathrm{NO}+\mathrm{O}_{2}$ mixture, $\mathrm{Pd}$ was not reduced to $\mathrm{Pd}^{0}$ for $\mathrm{Pd}(1.0) / \mathrm{Ce}_{0.5} \mathrm{Zr}_{0.5} \mathrm{O}_{2}$ up to reaction temperature as high as $400^{\circ} \mathrm{C}$, but remained in an oxidised state due to contact between $\mathrm{PdO}$ clusters and ceriazirconia [72]. It is, thus, very likely that the same conclusion also applies to the $\mathrm{Pd} / \mathrm{CZ}$ catalysts of the present work. This assumption is supported by: (i) the TPR traces revealing greater interaction of the Pd species with $\mathrm{CZ}$ than with $\mathrm{SiO}_{2}$ (Fig. 1), and (ii) the steady-state catalytic results (Table 4 and Table 6) that show markedly different $\mathrm{N}_{2}$ selectivity for $\mathrm{Pd} / \mathrm{CZ}$ and $\mathrm{Pd} / \mathrm{SiO}_{2}$ catalysts. The $\mathrm{N}_{2}$ selectivity found over the $\mathrm{Pd} / \mathrm{CZ}$ catalysts is, indeed, more than twice that observed over $\mathrm{Pd} / \mathrm{SiO}_{2}$. The $\mathrm{N}_{2}$ selectivity listed for $\mathrm{Pd} / \mathrm{SiO}_{2}$ agrees well with those already reported over a comparable catalytic system [19], over $\mathrm{Pd} / \mathrm{Al}_{2} \mathrm{O}_{3}$ [34] or over $\mathrm{Pt}^{0}$ clusters [19]. This means that $\mathrm{PdO}$ is reduced to $\mathrm{Pd}^{0}$ when being supported on $\mathrm{SiO}_{2}$ even under a lean atmosphere. Such a conclusion has also been reported by Fernàndez-Garcia et al. for alumina-supported Pd catalysts [72]. As already mentioned above, however, these authors 
1 have demonstrated that this was not the case for a $\mathrm{Pd}(1.0) / \mathrm{Ce}_{0.5} \mathrm{Zr}_{0.5} \mathrm{O}_{2}$ catalyst. The obvious

2 higher $\mathrm{N}_{2}$ selectivity for the $\mathrm{Pd} / \mathrm{CZ}$ catalysts might also suggest that the $\mathrm{deNO}_{\mathrm{x}}$ mechanism

3 occurring over these materials is different from the dissociation mechanism reported over

4 zero-valent PGMs atoms [6,9] and, thus, that the nature of the Pd species of the Pd/CZ

5 catalysts is different from that of $\mathrm{Pd}^{0}$. These arguments are further supported by the

6 comparison of the light-off of $\mathrm{C}_{3} \mathrm{H}_{6}$ of the TPSR and reverse TPSR (see part 3.1.10.) that

7 decreases to a significant extent on $\mathrm{Pd}(0.93) / \mathrm{SiO}_{2}$, and it is hardly affected at all on $\mathrm{Pd} / \mathrm{CZ}$

8 catalysts. Under the experimental conditions of the present study, it is, therefore, very likely

9 that $\mathrm{Pd}$ is present as $\mathrm{PdO}_{\mathrm{x}}$ species, with $\mathrm{x}$ close to unity [73], rather than $\mathrm{Pd}^{0}$.

\subsection{Lean deNO $O_{x}$ mechanism proposal over $P d O_{x} / C Z$ catalysts}

The results of the present work show that the incorporation of $\mathrm{Pd}$ to $\mathrm{CZ}$ promotes significantly lean deNO ${ }_{x}$ activity (Fig. 10). In addition, CZ-supported catalysts exhibit a much higher $\mathrm{N}_{2}$ selectivity compared with that of $\mathrm{Pd}^{0}(0.93) / \mathrm{SiO}_{2}$ (Table 4). Centi et al. [31] and Liotta et al. [32] have also recently reported elevated $\mathrm{N}_{2}$ selectivities over $\mathrm{Pt} / \mathrm{Ce}_{0.60} \mathrm{Zr}_{0.40} \mathrm{O}_{2^{-}}$ $\mathrm{Al}_{2} \mathrm{O}_{3}$ and $\mathrm{Pt} / \mathrm{Ce}_{0.60} \mathrm{Zr}_{0.40} \mathrm{O}_{2}$ catalysts. These authors, however, did not comment about this peculiarity. As already mentioned in the preceding characterisation section, this obvious difference in $\mathrm{N}_{2}$ selectivity between $\mathrm{Pd}^{0} / \mathrm{SiO}_{2}$ and $\mathrm{PdO}_{\mathrm{x}} / \mathrm{CZ}$ catalysts suggests that the lean deNO $\mathrm{x}_{\mathrm{x}}$ mechanism occurring over $\mathrm{PdO}_{\mathrm{x}} / \mathrm{CZ}$ catalysts is different from that occurring over $\mathrm{Pd}^{0} / \mathrm{SiO}_{2}$. The fairly low $\mathrm{N}_{2}$ selectivity found for $\mathrm{Pd}^{0} / \mathrm{SiO}_{2}$ (Table 4) indicates that lean $\mathrm{deNO}_{\mathrm{x}}$ most likely proceeds through the NO dissociation mechanism [9] on zero-valent Pd clusters, the oxygen left from NO dissociation on the reduced surface being "cleaned" by the $\mathrm{C}_{3} \mathrm{H}_{6}$ oxidation reaction.

In a recent article [38], we suggested that reaction intermediates such as $\mathrm{NO}_{2}$, organic nitrogen-containing compounds $\left(\mathrm{RNO}_{\mathrm{x}}\right)$ and oxygenates $\left(\mathrm{C}_{\mathrm{x}} \mathrm{H}_{\mathrm{y}} \mathrm{O}_{\mathrm{z}}\right)$ might be involved in the 
1 lean deNO $\mathrm{Na}_{\mathrm{x}}$ catalysis on $\mathrm{CZ}$. In the proposed mechanism, the production of $\mathrm{NO}_{2}$ and $\mathrm{C}_{\mathrm{x}} \mathrm{H}_{\mathrm{y}} \mathrm{O}_{\mathrm{z}}$,

2 the formation of the latter resulting from the decomposition of $\mathrm{R}-\mathrm{NO}_{\mathrm{x}}$ intermediates produced

3 by the reaction of $\mathrm{NO}_{2}$ and $\mathrm{C}_{3} \mathrm{H}_{6}$, has been assumed to be critical for lean deNO $\mathrm{x}_{\mathrm{x}}$ activity, as

4 also reported by other authors [34]. The present study also shows that $\mathrm{NO}$ oxidation to $\mathrm{NO}_{2}$ is

5 achieved on the bare support, as the introduction of Pd does not promote such a reaction (Fig.

6 5). This conclusion is consistent with the work of Krishna et al. in which the authors reported

7 that $\mathrm{CeO}_{2}$ is a fairly efficient catalyst in the oxidation of NO [74].

The activation of $\mathrm{C}_{3} \mathrm{H}_{6}$ proceeds unambiguously on the $\mathrm{PdO}_{\mathrm{x}}$ catalytic function, as

demonstrated by the $\mathrm{C}_{3} \mathrm{H}_{6}$ light-off temperature that decreases significantly over supported $\mathrm{Pd}$ catalysts (Fig. 10 and Table 3). In addition, it is obvious that this low temperature activation of $\mathrm{C}_{3} \mathrm{H}_{6}$ is responsible for the lean deNO $\mathrm{N}_{\mathrm{x}}$ activity of $\mathrm{PdO}_{\mathrm{x}} / \mathrm{CZ}$ catalysts, as both $\mathrm{C}_{3} \mathrm{H}_{6}$ activation and deNO ${ }_{x}$ occur concomitantly (Fig. 9 and Fig. 10c,d).

One might, however, wonder about the activation process of $\mathrm{C}_{3} \mathrm{H}_{6}$ in the course of the deNO $\mathrm{N}_{\mathrm{x}}$ reaction. On that point, the TPD in $\mathrm{C}_{3} \mathrm{H}_{6}-\mathrm{O}_{2}$ after adsorption of $\mathrm{NO}-\mathrm{O}_{2}$ is very informative. Fig. $7 \mathrm{~b}$ shows that $\mathrm{C}_{3} \mathrm{H}_{6}$ is activated through ad- $\mathrm{NO}_{2}$ species, as already proposed on $\mathrm{CZ}$ [38], the low temperature $\left(130-180^{\circ} \mathrm{C}\right)$ consumption of $\mathrm{C}_{3} \mathrm{H}_{6}$ being different from the $\mathrm{C}_{3} \mathrm{H}_{6}$ profiles observed in the $\mathrm{C}_{3} \mathrm{H}_{6}-\mathrm{O}_{2}$ reaction on $\mathrm{Pd}(0.89) / \mathrm{CZ}$ (Fig. 8) and in the TPD in $\mathrm{C}_{3} \mathrm{H}_{6}-\mathrm{O}_{2}$ after adsorption of $\mathrm{NO}-\mathrm{O}_{2}$ on $\mathrm{CZ}$ (Fig. 7a). In this temperature range, it is worthwhile noting that the $\mathrm{NO}_{2}$ concentration of the TPD in $\mathrm{N}_{2}$ after adsorption of $\mathrm{NO}-\mathrm{O}_{2}$ on $\mathrm{Pd}(0.89) / \mathrm{CZ}$ is greater than that of $\mathrm{CZ}$ (Fig. 6c, $130-180^{\circ} \mathrm{C}$ region). These observations strongly suggest that $\mathrm{NO}_{2}$ species adsorbed on the $\mathrm{PdO}_{\mathrm{x}}$ catalytic function account for the activation of $\mathrm{C}_{3} \mathrm{H}_{6}$. Such a conclusion is also supported by the fact that $\mathrm{NO}$ is mainly desorbed in the TPD in $\mathrm{C}_{3} \mathrm{H}_{6}-\mathrm{O}_{2}$ after adsorption of $\mathrm{NO}-\mathrm{O}_{2}$ (Table 2), whereas $\mathrm{NO}_{2}$ would have been expected to be the most abundant desorbed compound from the TPD in $\mathrm{N}_{2}$ (Table 2 and Fig. 6b). As discussed previously [38], the activation of $\mathrm{C}_{3} \mathrm{H}_{6}$ by ad- $\mathrm{NO}_{2}$ and the 
1 concomitant release of $\mathrm{NO}$ might be attributed to the intermediate formation of $\mathrm{R}-\mathrm{NO}_{\mathrm{x}}$

2 compounds, the decomposition of which produces $\mathrm{NO}$ and $\mathrm{C}_{\mathrm{x}} \mathrm{H}_{\mathrm{y}} \mathrm{O}_{\mathrm{z}}$.

One might wonder whether lean $\mathrm{deNO}_{\mathrm{x}}$ also occurs on the $\mathrm{PdO}_{\mathrm{x}}$ catalytic function.

4 Given that lean deNO $\mathrm{O}_{\mathrm{x}}$ occurs to a significant extent on $\mathrm{CZ}$ when $\mathrm{C}_{3} \mathrm{H}_{6}$ is substituted by 1-

$5 \mathrm{C}_{3} \mathrm{H}_{7} \mathrm{OH}$ (Fig. 12), it seems more likely that $\mathrm{NO}$ reduction takes place via a lacunar

6 mechanism on reduced CZ sites, as proposed by several groups [75-78]. These authors,

7 indeed, provided evidence for the decomposition of $\mathrm{NO}$ to $\mathrm{N}_{2}$ on prereduced $\mathrm{CeO}_{2}$ surfaces. It

8 is worth reporting that this decomposition pathway has also been considered in Three-Way

9 Catalysis in which $\mathrm{CO}$ is used as reductant [15]. In the course of the lean deNO $\mathrm{x}_{\mathrm{x}}$ reaction, the

creation of the sites responsible for the decomposition of NO would, thus, be achieved by

11 reduction of $\mathrm{CZ}$ by the oxygenates $\left(\mathrm{C}_{\mathrm{x}} \mathrm{H}_{\mathrm{y}} \mathrm{O}_{\mathrm{z}}\right)$ produced by the decomposition of $\mathrm{R}-\mathrm{NO}_{\mathrm{x}}$

12 formed on the $\mathrm{PdO}_{\mathrm{x}}$ catalytic function.

The corresponding detailed mechanism of the $\mathrm{C}_{3} \mathrm{H}_{6}$-assisted decomposition of NO on $\mathrm{PdO}_{\mathrm{x}} / \mathrm{CZ}$ catalysts is described in Fig. 13. This mechanism stresses the key role of $\mathrm{NO}_{2}, \mathrm{R}-$ $\mathrm{NO}_{\mathrm{x}}$ and $\mathrm{C}_{\mathrm{x}} \mathrm{H}_{\mathrm{y}} \mathrm{O}_{\mathrm{z}}$ as intermediates of the Selective Catalytic Reduction (SCR) of $\mathrm{NO}_{\mathrm{x}}$ by hydrocarbons, as also suggested in many studies [34,38 and references therein]. The proposed mechanism is consistent with previous studies of Djega-Mariadassou [16,79] who reported that three catalytic functions were required for the occurrence of the SCR of $\mathrm{NO}_{\mathrm{x}}$ by hydrocarbons. In this model, $\mathrm{CZ}$ achieves both $\mathrm{NO}$ oxidation to $\mathrm{NO}_{2}$ (cycle 1) and $\mathrm{NO}$ decomposition to $\mathrm{N}_{2}$ (cycle 3), whereas $\mathrm{PdO}_{\mathrm{x}}$ activates $\mathrm{C}_{3} \mathrm{H}_{6}$ via ad- $\mathrm{NO}_{2}$ species (cycle 2)

21 intermediately producing $\mathrm{R}-\mathrm{NO}_{\mathrm{x}}$ compounds that further decompose to $\mathrm{NO}$ and $\mathrm{C}_{\mathrm{x}} \mathrm{H}_{\mathrm{y}} \mathrm{O}_{\mathrm{z}}$. The 22 role of the latter oxygenates is to reduce $\mathrm{CZ}$ to provide the catalytic sites responsible for NO decomposition (catalytic cycle 3). In the proposed mechanism, the reaction of $\mathrm{NO}_{2}$ with $\mathrm{C}_{3} \mathrm{H}_{6}$ to give NO back and the competition between the NO oxidation and decomposition reactions on the $\mathrm{CZ}$ catalytic sites also account for the limited formation of $\mathrm{NO}_{2}$ in the course of the 
1 lean deNO $\mathrm{N}_{\mathrm{x}}$ process (Fig. 7b, Fig. 9 and Fig. 10e). At elevated temperatures, complete

2 oxidation of $\mathrm{C}_{3} \mathrm{H}_{6}$ by molecular $\mathrm{O}_{2}$ becomes predominant [80] on $\mathrm{PdO}_{\mathrm{x}}$, and the $\mathrm{deNO}_{\mathrm{x}}$ 3 process cannot proceed further.

\section{Conclusion}

This study shows that the incorporation of $\mathrm{Pd}$ to $\mathrm{CZ}$ greatly promotes the reduction of $\mathrm{NO}$ in the presence of $\mathrm{C}_{3} \mathrm{H}_{6}$. These catalysts display very stable deNO $\mathrm{N}_{\mathrm{x}}$ activity even in the presence of $1.7 \%$ water, the addition of which induces a reversible deactivation of about $10 \%$.

Ex situ characterisation of the catalysts through propene hydrogenation reaction, XRD, XANES, CO absorption followed by FTIR along with the catalytic results indicate that PdO is reduced to $\mathrm{Pd}^{0}$ clusters on $\mathrm{Pd} / \mathrm{SiO}_{2}$, this catalyst having been studied as a reference catalyst. This complete reduction process, however, does not occur for $\mathrm{PdO}_{\mathrm{x}} / \mathrm{CZ}$ catalysts under our experimental conditions.

The $\mathrm{PdO}_{\mathrm{x}} / \mathrm{CZ}$ catalysts also exhibit much higher selectivity to $\mathrm{N}_{2}$ than that of $\mathrm{Pd}^{0} / \mathrm{SiO}_{2}$, the selectivity of which is consistent with those already reported in literature data over supported zero-valent noble metal catalysts. The much higher $\mathrm{N}_{2}$ selectivity obtained on $\mathrm{PdO}_{\mathrm{x}} / \mathrm{CZ}$ suggests that the lean $\mathrm{deNO}_{\mathrm{x}}$ mechanism occurring on these catalysts is different 18 from that occurring on $\mathrm{Pd}^{0} / \mathrm{SiO}_{2}$ which consists of the dissociation of $\mathrm{NO}$ on reduced palladium sites, followed by the regeneration of the active $\mathrm{Pd}^{0}$ sites by $\mathrm{C}_{3} \mathrm{H}_{6}$. The results of the catalytic experiments led us to propose a detailed mechanism (Fig. 13) for which CZ 21 achieves both $\mathrm{NO}$ oxidation to $\mathrm{NO}_{2}$ and $\mathrm{NO}$ decomposition to $\mathrm{N}_{2}$, whereas $\mathrm{PdO}_{\mathrm{x}}$ activates $22 \mathrm{C}_{3} \mathrm{H}_{6}$ via ad- $\mathrm{NO}_{2}$ species, intermediately producing $\mathrm{R}-\mathrm{NO}_{\mathrm{x}}$ compounds that further decompose to $\mathrm{NO}$ and $\mathrm{C}_{\mathrm{x}} \mathrm{H}_{\mathrm{y}} \mathrm{O}_{\mathrm{z}}$. The role of the latter oxygenates is to reduce $\mathrm{CZ}$ to provide the catalytic sites responsible for $\mathrm{NO}$ decomposition. Finally, the proposed $\mathrm{C}_{3} \mathrm{H}_{6}$-assisted NO 
1 decomposition mechanism stresses the key role of $\mathrm{NO}_{2}, \mathrm{R}-\mathrm{NO}_{\mathrm{x}}$ and $\mathrm{C}_{\mathrm{x}} \mathrm{H}_{\mathrm{y}} \mathrm{O}_{\mathrm{z}}$ as intermediates

2 of the Selective Catalytic Reduction (SCR) of $\mathrm{NO}_{\mathrm{x}}$ by hydrocarbons.

3

4

[1] K.C. Taylor, in Catalysis Science and Technology, J.R. Anderson, M. Boudart, Automobile Catalytic Converters, Springler-Verlag, Berlin, 1982, p. 119.

[2] M. Shelef, G.W. Graham, Catal. Rev. Sci. Eng. 36 (1994) 431.

[3] M.D. Amiridis, T. Zhang, R.J. Farrauto, App. Catal. B: Env. 10 (1996) 203.

[4] V.I. Pârvulescu, P. Grange, B. Delmon, Catal. Today 46 (1998) 233.

[5] R.J. Farrauto, R.M. Heck, Catal. Today 51 (1999) 351.

[6] R. Burch, J.P. Breen, F.C. Meunier, Appl. Catal. B: Env. 39 (2002) 283.

[7] F. Fajardie, J.-F. Tempère, J.-M. Manoli, O. Touret, G. Blanchard, G. DjégaMariadassou, J. Catal. 179 (1998) 469.

[8] T.W. Root, L.D. Schmidt, G.B. Fischer, Surf. Sci. 134 (1983) 30.

[9] R. Burch, P.J. Millington, A.P. Walker, Appl. Catal. B: Env. 4 (1994) 65.

[10] R. Burch, P.K. Loader, N.A. Cruise, Appl. Catal. A: Gen. 147 (1996) 375.

[11] N. Miyoshi, S. Matsumoto, K. Katoh, T. Tanaka, J. Harada, N. Takahashi, K. Yokota, M. Sugiura, K. Kasahara, SAE 950809, 1995. 
[12] M. Iwamoto, H. Furukawa, Y. Mina, F. Uemura, S. Mikuriya, S. Kagawa, J. Chem. Soc. Chem. Com. (1986) 1275.

[13] M. Iwamoto, K. Maruyama, N. Yamazoe, T. Seiyama, J. Chem. Soc. Chem. Com. (1966) 615.

[14] Y. Lee, J.N. Armor, App. Catal. 76 (1995) L1.

[15] G. Djéga-Mariadassou, F. Fajardie, J.-F. Tempère, J.-M. Manoli, O. Touret, G. Blanchard, J. Mol. Catal. A: Chem. 161 (2000) 179.

[16] G. Djéga-Mariadassou, Catal. Today 90 (2004) 27.

[17] S. Matsumoto, K. Yokota, H. Doi, M. Kimura, S. Kasahura, Catal. Today 22 (1994) 127.

[18] K. Yogo, M. Umeno, H. Watanabe, E. Kikuchi, Catal. Lett. 19 (1993) 131.

[19] R. Burch, P.J. Millington, Catal. Today 29 (1996) 37.

[20] G.R. Bamwenda, A. Ogata, A. Obuchi, J. Oi, K. Mizuno, J. Skrzypek, Appl. Catal. B: Env. 6 (1995) 311.

[21] J. Li, J. Hao, L. Fu, T. Zhu, Topics Catal. 30/31 (2004) 81.

[22] T. Tanaka, T. Okuhara, M. Misono, Appl. Catal. B: Env. 4 (1994) L1.

[23] R. Burch, T.C. Watling, Catal Lett. 37 (1996) 51.

[24] R. Burch, T.C. Watling, Catal Lett. 43 (1997) 19.

[25] T. Okuhara, Y. Hasada, M. Misono, Catal. Today 35 (1997) 83.

[26] R. Burch, T.C. Watling, Appl. Catal. B: Env. 11 (1997) 207.

[27] R. Burch, J.A. Sullivan, T.C. Watling, Catal. Today 42 (1998) 13.

[28] E. Joubert, T. Bertin, J.C. Ménézo, J. Barbier, Appl. Catal. B: Env. 23 (1999) L83.

[29] D.K. Captain, K.L. Roberts, M.D. Amiridis, Catal. Today 42 (1998) 93.

[30] P. Denton, A. Giroir-Fendler, H. Praliaud, M. Primet, J. Catal. 189 (2000) 410. 
[31] G. Centi, P. Fornasiero, M. Graziani, J. Kašpar, F. Vazzana, Topics Catal. 16/17 (2001) 157.

[32] L.F. Liotta, A. Longo, A. Macaluso, A. Martorana, G. Pantaleo, A.M. Venezia, G. Deganello, Appl. Catal. B: Env. 48 (2004) 133.

[33] A. Obuchi, A. Ogata, H. Takahashi, J. Oi, G.R. Bamwenda, K. Mizuno, Catal. Today 29 (1996) 103.

[34] K.O. Haj, S. Ziyade, M. Ziyad, F. Garin, Appl. Catal. B: Env. 37 (2002) 49.

[35] Y. Traa, B. Burger, J. Weitkamp, J. Chem. Soc. Chem. Comm. 21 (1999) 2187.

[36] P. Degobert, Automobiles and Pollution (Institut Français du Pétrole Publications, Editions Technip, Paris 1995)

[37] S.N. Orlik, V.L. Struzhko, T.V. Mironyuk, G.M. Tel'biz, Theor. Exp. Chem. 37 (2001) 311.

[38] O. Gorce, F. Baudin, C. Thomas, P. Da Costa, G. Djéga-Mariadassou, Appl. Catal. B: Env. 54 (2004) 69.

[39] R. Rajasree, J.H.B.J. Hoebink, J.C. Shouten, J. Catal. 223 (2004) 36.

[40] N. Hickey, P. Fornasiero, R. Di Monte, J. Kašpar, J.R. González-Velasco, M.A. Gutiérrez-Ortiz, M.P. González-Marcos, J.M. Gatica, S. Bernal, J. Chem. Soc., Chem. Commun. (2004) 196.

[41] S. Bedrane, C. Descorme, D. Duprez, Catal. Today 75 (2002) 41.

[42] S. Salasc, V. Perrichon, M. Primet, N. Mouaddib-Moral, J. Catal. 206 (2002) 82.

[43] A. Iglesia-Juez, A. Martínez-Arias, M. Fernández-García, J. Catal. 221 (2004) 148.

[44] C. Bozo, N. Guilhaume, J.-M. Herrmann, J. Catal. 203 (2001) 393.

[45] G. Pecchi, P. Reyes, R. Zamora, T. Lopez, R. Gomez, J. Chem. Tech. Biotech. 80 (2005) 268 . 
[46] J. Breen, R. Burch, H.M. Coleman, Appl. Catal. B: Env. 39 (2002) 65.

[47] S.H. Overbury, D.R. Mullins, in Catalyis by Ceria and Related Materials, A. Trovarelli (Ed.), Ceria Surfaces and Films for Model Catalytic Studies Using Surface Analysis Techniques, Imperial College Press, London, 2002, p.328.

[48] L. Salin, C. Potvin, J.-F. Tempère, M. Boudart, G. Djéga-Mariadassou and J.-M. Bart, Ind. Eng. Chem. Res. 37 (1998) 4531.

[49] A. Michalowicz, Logiciels pour la chimie; Société Française de Chimie, Paris (1991) 102.

[50] A. Michalowicz, J. Phys. IV France 7 (1997) 235.

[51] C. de Leitenburg, A. Trovarelli, J. Kašpar, J. Catal. 166 (1997) 98.

[52] H.-W. Jen, G.W. Graham, W. Chun, R.W. McCabe, J.-P. Cuif, S.E. Deutsch, O. Touret, Catal. Today 50 (1999) 309.

[53] R. Di Monte, P. Fornasiero, M. Graziani, J. Kašpar, J. Alloys Comp. 275-277 (1998) 877.

[54] P. Fornasiero, N. Hickey, J. Kašpar, T. Montini, M. Graziani, J. Catal. 189 (2000) 339.

[55] P. Fornasiero, J. Kašpar, M. Graziani, J. Catal. 167 (1997) 576.

[56] M.-F. Luo, X.-M. Zheng, Appl. Catal. A: General 189 (1999) 15.

[57] P. Fornasiero, R. Di Monte, G. Ranga Rao, J. Kašpar, S. Meriani, A. Trovarelli, M. Graziani, J. Catal. 151 (1995) 168

[58] C. Fontaine, C. Thomas, J.-M. Krafft, O. Gorce, F. Villain, G. Djéga-Mariadassou, in preparation.

[59] K. Hadjiivanov, G.N. Vayssilov, Adv. Catal. 47 (2002) 307.

[60] J.-C. Lavalley, J. Saussey, J. Lamotte, R. Breault, J. P. Hindermann, A. Kiennemann, J. Phys. Chem. 94 (1990) 5941. 
[61] A. Badri, C. Binet, J.-C. Lavalley, J. Phys. Chem. 100 (1996) 8363.

[62] A. Badri, C. Binet, J.-C. Lavalley, J. Chem. Soc., Farad. Trans. 92 (1996) 1603.

[63] A. Bensalem, J.-C. Muller, D. Tessier, F. Bozon-Verduraz, J. Chem. Soc., Farad. Trans. 92 (1996) 3233.

[64] C. Force, J. P. Belzunegui, J. Sanz, A. Martínez-Arias, J. Soria, J. Catal. 197 (2001) 192.

[65] K.I. Choi, M.A. Vannice, J. Catal. 127 (1991) 465.

[66] L. Sordelli, G. Matra, R. Psaro, S. Coluccia, J. Chem. Soc., Dalton Trans. 5 (1996) 765.

[67] M. Ogura, M. Hayashi, S. Kage, M. Matsukata, E. Kikuchi, Appl. Catal. B: Env. 23 (1999) 247.

[68] J.H. Holles, R.J. Davis, J. Phys. Chem. B 104 (2000) 9653.

[69] W-J. Shen, Y. Ichihashi, M. Okumara, Y. Matsumara, Catal. Lett. 64 (2000) 23.

[70] Y. Matsumara, M. Okumara, Y. Usami, K. Kagawa, H. Yamashita, M. Anpo, M. Haruta, Catal. Lett. 44 (1997) 189.

[71] M. Vaarkamp, D.C. Koningsberger, in G. Ertl, H. Knözinger, J. Weitkamp (Ed.), Handbook of Heterogeneous Catalysis, Wiley-VCH, Weinheim, 1997, Vol. 2, p. 475.

[72] M. Fernàndez-Garcia, A. Iglesia-Juez, A. Martínez-Arias, A.B. Hungría, J.A. Anderson, J.C. Conesa, J. Soria, J. Catal. 221 (2004) 594.

[73] T. Maillet, C. Solleau, J. Barbier Jr., D. Duprez, Appl. Catal. B: Env. 14 (1997) 85.

[74] K. Krishna, M. Makkee, Appl. Catal. B: Env. 59 (2005) 35.

[75] M. Niwa, Y. Furukawa, Y. Murakami, J. Coll. Int. Sci. 86 (1982) 260.

[76] A. Martinez-Arias, J. Soria, J.C. Conesa, X.L. Soane, A. Arcoya, R. Cataluna, J. Chem. Soc. Faraday. Trans. 91 (1995) 1679. 
[77] S.H. Overbury, D.R. Mullins, D.R. Huntley, Lj. Kundakovic, J. Catal. 186 (1999) 296.

[78] M. Daturi, N. Bion, J. Saussey, J.-C. Lavalley, C. Hedouin, T. Seguelon, G. Blanchard, Phys. Chem. Chem. Phys. 3 (2001) 252.

[79] G. Djéga-Mariadassou, M. Boudart, J. Catal. 216 (2003) 89.

[80] J. Haber, W. Turek, J. Catal. 190 (2000) 320. 
Table 1: Determination of the percentage of exposed zero-valent Pd atoms $\left(\mathrm{PEM}^{0}\right)$ over $\mathrm{Ce}_{0.68} \mathrm{Zr}_{0.32} \mathrm{O}_{2}$ (CZ)- and silica-supported catalysts by means of propene hydrogenation reactions [48].

\begin{tabular}{cccc} 
Catalysts & $\mathrm{Pd}(0.54) / \mathrm{CZ}$ & $\mathrm{Pd}(0.89) / \mathrm{CZ}$ & $\mathrm{Pd}(0.93) / \mathrm{SiO}_{2}$ \\
$\mathrm{Pd}^{0}(\%)$ & 17 & 16 & 22 \\
\hline
\end{tabular}


Table 2: Amounts of adsorbed or desorbed $\mathrm{NO}_{\mathrm{x}}\left(\mathrm{NO}+\mathrm{NO}_{2}\right)$ and desorbed $\mathrm{N}_{2} \mathrm{O}$ in the course of the TPD experiments after exposure of the catalysts to $\mathrm{NO}-\mathrm{O}_{2}(340 \mathrm{ppm}-8 \%)$ in $\mathrm{N}_{2}$

Amounts of adsorbed (ads.) or desorbed (des.) species $\left(10^{-5} \mathrm{~mol} \mathrm{~g}^{-1}\right)$

\begin{tabular}{|c|c|c|c|c|c|c|c|}
\hline Catalysts & experiment & $\mathrm{NO}_{\mathrm{x}}$ ads. & $\mathrm{NO}_{\text {des. }}$ & $\mathrm{NO}_{2}$ des. & $\mathrm{NO}_{\mathrm{x}}$ des. & $\mathrm{N}_{2} \mathrm{O}_{\text {des. }}$ & $\mathrm{N}$ balance* \\
\hline \multirow[t]{2}{*}{$\mathrm{Ce}_{0.68} \mathrm{Zr}_{0.32} \mathrm{O}_{2}(\mathrm{CZ})$} & $\mathrm{TPD}$ in $\mathrm{N}_{2}$ & 54.8 & 8.1 & 46.5 & 54.6 & 0.0 & 0.1 \\
\hline & $\mathrm{TPD}$ in $\mathrm{C}_{3} \mathrm{H}_{6}-\mathrm{O}_{2}$ & 48.2 & 19.0 & 7.8 & 26.8 & 5.8 & 4.9 \\
\hline \multirow[t]{2}{*}{$\mathrm{Pd}(0.89) / \mathrm{CZ}$} & $\mathrm{TPD}$ in $\mathrm{N}_{2}$ & 47.6 & 6.2 & 36.4 & 42.7 & 0.0 & 2.5 \\
\hline & TPD in $\mathrm{C}_{3} \mathrm{H}_{6}-\mathrm{O}_{2}$ & 51.8 & 20.3 & 5.1 & 25.4 & 5.4 & 7.8 \\
\hline
\end{tabular}

$* \mathrm{~N}$ balance calculated with respect to $\mathrm{N}_{2}$ equivalent 
Table 3: $\mathrm{C}_{3} \mathrm{H}_{6}$ light-off temperatures $\left({ }^{\circ} \mathrm{C}\right)$ of $\mathrm{Ce}_{0.68} \mathrm{Zr}_{0.32} \mathrm{O}_{2}(\mathrm{CZ})$ - and silica-supported catalysts; 340ppm NO, $8 \% \mathrm{O}_{2}, 1900 \mathrm{ppm} \mathrm{C}_{3} \mathrm{H}_{6}$ and $\mathrm{N}_{2}$ balance

\begin{tabular}{|c|c|c|c|c|}
\hline & Ads $\mathrm{NO}-\mathrm{O}_{2}$ & Transient & Transient & Steady-state \\
\hline & $\mathrm{TPD}$ in $\mathrm{O}_{2}-\mathrm{C}_{3} \mathrm{H}_{6}$ & $\mathrm{O}_{2}-\mathrm{C}_{3} \mathrm{H}_{6}$ & $\mathrm{NO}-\mathrm{O}_{2}-\mathrm{C}_{3} \mathrm{H}_{6}$ & $\mathrm{NO}-\mathrm{O}_{2}-\mathrm{C}_{3} \mathrm{H}_{6}$ \\
\hline $\mathrm{CZ}$ & 450 & 473 & 387 & 380 \\
\hline $\mathrm{Pd}(0.54) / \mathrm{CZ}$ & - & 277 & 276 & 303 \\
\hline $\mathrm{Pd}(0.89) / \mathrm{CZ}$ & 276 & 251 & 252 & 243 \\
\hline \multirow[t]{2}{*}{$\mathrm{Pd}(0.93) / \mathrm{SiO}_{2}$} & - & - & $298 *$ & - \\
\hline & & 236 & 237 & 237 \\
\hline
\end{tabular}

\footnotetext{
* Light-off temperature measured in the course of the first NO- $\mathrm{O}_{2}-\mathrm{C}_{3} \mathrm{H}_{6}$ TPSR
} 
Table 4: Temperature of maximum of $\mathrm{N}_{2}$ formation and percentage of $\mathrm{NO}_{\mathrm{x}}$ converted to $\mathrm{N}_{2}$ at this temperature over $\mathrm{Ce}_{0.68} \mathrm{Zr}_{0.32} \mathrm{O}_{2}(\mathrm{CZ})$-and silica-supported catalysts for the steady-state NO- $\mathrm{O}_{2}-\mathrm{C}_{3} \mathrm{H}_{6}$ reaction (340 ppm - $8 \%-1900 \mathrm{ppm}, \mathrm{N}_{2}$ balance)

\begin{tabular}{ccccc}
\hline Catalysts & $\mathrm{CZ}$ & $\mathrm{Pd}(0.54) / \mathrm{CZ}$ & $\mathrm{Pd}(0.89) / \mathrm{CZ}$ & $\mathrm{Pd}(0.93) / \mathrm{SiO}_{2}$ \\
\hline Sample Weight $(\mathrm{g})$ & 0.20 & 0.20 & 0.20 & 0.07 \\
$\mathrm{~T} \max \mathrm{N}_{2}\left({ }^{\circ} \mathrm{C}\right)$ & 361 & 263 & 243 & 243 \\
Conversion of $\mathrm{NO}_{\mathrm{x}}$ to $\mathrm{N}_{2}(\%)$ & 8 & 21 & 29 & 7 \\
Selectivity to $\mathrm{N}_{2}(\%) *$ & 81 & 83 & 87 & 28 \\
$\mathrm{C}_{3} \mathrm{H}_{6}$ conversion $(\%)$ & 34 & 38 & 50 & 58 \\
\hline
\end{tabular}

* Selectivity to $\mathrm{N}_{2}$ referred to as $\left(\mathrm{N}_{2} /\left(\mathrm{N}_{2}+\mathrm{N}_{2} \mathrm{O}\right) \times 100\right)$ 
Table 5: Influence of the addition of $1.7 \%$ water on the conversions of $\mathrm{C}_{3} \mathrm{H}_{6}$ and $\mathrm{NO}_{\mathrm{x}}$ to $\mathrm{N}_{2}$ at $278^{\circ} \mathrm{C}$ in the course of the $\mathrm{C}_{3} \mathrm{H}_{6}-\mathrm{NO}-\mathrm{O}_{2}$ reaction (1900 ppm- $340 \mathrm{ppm}-8 \%$, balance $\mathrm{N}_{2}$ ) versus time on stream on $\mathrm{Pd}(0.89) / \mathrm{Ce}_{0.68} \mathrm{Zr}_{0.32} \mathrm{O}_{2}$.

Time on stream (h)

\begin{tabular}{ccccc} 
& 0 & 1 & 20 & 20.5 \\
\hline $\mathrm{H}_{2} \mathrm{O}(\%)$ & 0 & 1.7 & 1.7 & 0 \\
Conversion of $\mathrm{NO}_{\mathrm{x}}$ to $\mathrm{N}_{2}(\%)$ & 27 & 24 & 25 & 29 \\
Selectivity to $\mathrm{N}_{2}(\%)^{*}$ & 75 & 76 & 76 & 77 \\
$\mathrm{C}_{3} \mathrm{H}_{6}$ conversion $(\%)$ & 65 & 62 & 62 & 60 \\
\hline
\end{tabular}

* Selectivity to $\mathrm{N}_{2}$ referred to as $\left(\mathrm{N}_{2} /\left(\mathrm{N}_{2}+\mathrm{N}_{2} \mathrm{O}\right)\right.$ x 100$)$ 
Table 6: Percentage of $\mathrm{NO}_{\mathrm{x}}$ converted to $\mathrm{N}_{2}$ over $\mathrm{Ce}_{0.68} \mathrm{Zr}_{0.32} \mathrm{O}_{2}$ (CZ)-and silica-supported catalysts for the steady-state $\mathrm{NO}-\mathrm{O}_{2}-\mathrm{C}_{3} \mathrm{H}_{6}$ reaction (340 ppm- $8 \%-1900 \mathrm{ppm}, \mathrm{N}_{2}$ balance)

\begin{tabular}{ccc}
\hline Catalysts & $\mathrm{Pd}(0.89) / \mathrm{CZ}+\mathrm{SiO}_{2}$ & $\mathrm{Pd}(0.93) / \mathrm{SiO}_{2}+\mathrm{CZ}$ \\
\hline Sample Weight $(\mathrm{g})$ & $0.10+0.10$ & $0.10+0.10$ \\
$\mathrm{~T}\left({ }^{\circ} \mathrm{C}\right)$ & 250 & 255 \\
& 29 & 12 \\
Conversion of $\mathrm{NO}_{\mathrm{x}}$ to $\mathrm{N}_{2}(\%)$ & & 51 \\
Selectivity to $\mathrm{N}_{2}(\%) *$ & 86 & 50 \\
$\mathrm{C}_{3} \mathrm{H}_{6}$ conversion $(\%)$ & 47 & \\
\hline
\end{tabular}

* Selectivity to $\mathrm{N}_{2}$ referred to as $\left(\mathrm{N}_{2} /\left(\mathrm{N}_{2}+\mathrm{N}_{2} \mathrm{O}\right)\right.$ x 100) 


\section{Figure captions}

Fig. 1: Temperature-Programmed Reduction profiles of the calcined (air $500^{\circ} \mathrm{C}, 2 \mathrm{~h}$ ) catalysts.

Fig. 2: XRD patterns of $\mathrm{SiO}_{2}, \mathrm{Pd}(0.93) / \mathrm{SiO}_{2}$ and $\mathrm{Ce}_{0.68} \mathrm{Zr}_{0.32} \mathrm{O}_{2}$.

Fig. 3: XANES spectra at the $\mathrm{Pd} K$ edge for $\mathrm{PdO}(\boldsymbol{\Delta})$, the $\mathrm{Pd}$ foil $(\Delta)$ and $\operatorname{Pd}(0.54) / \mathrm{CZ}$ (oxidized in air at $500^{\circ} \mathrm{C}$ : ---- or reduced in $\mathrm{H}_{2}$ at $500^{\circ} \mathrm{C}$ : - ).

Fig. 4: FT infrared spectra of (a) $\mathrm{Ce}_{0.68} \mathrm{Zr}_{0.32} \mathrm{O}_{2}$ (CZ) and (b) $\mathrm{Pd}(0.89) / \mathrm{CZ}$, reduced under flowing $\mathrm{H}_{2}$ at $500^{\circ} \mathrm{C}$ for $2 \mathrm{~h}$ and evacuation at $500^{\circ} \mathrm{C}$ for $1 \mathrm{~h}$, after introduction of equilibrated pressures of $0.9(--)$ and $18(-)$ torr of $\mathrm{CO}$.

Fig. 5: Steady-state catalytic conversion of $\mathrm{NO}$ oxidation to $\mathrm{NO}_{2}$ in the course of the $\mathrm{NO}-\mathrm{O}_{2}$ reaction (340 ppm - 8\%, balance $\mathrm{N}_{2}$ ): (•) $\mathrm{Ce}_{0.68} \mathrm{Zr}_{0.32} \mathrm{O}_{2}(\mathrm{CZ}),(\bullet) \mathrm{Pd}(0.54) / \mathrm{CZ}$.

Fig. 6: $\mathrm{NO}_{\mathrm{x}}$ Temperature-Programmed Desorption profiles in $\mathrm{N}_{2}$ after exposure of the catalysts to $\mathrm{NO}-\mathrm{O}_{2}\left(340 \mathrm{ppm}-8 \%\right.$, balance $\mathrm{N}_{2}$ ) at $\mathrm{RT}$ : (a) $\mathrm{Ce}_{0.68} \mathrm{Zr}_{0.32} \mathrm{O}_{2}$ (CZ), (b) $\mathrm{Pd}(0.89) / \mathrm{CZ}$ and (c) their comparison, the $\mathrm{NO}_{\mathrm{x}} \mathrm{TPD}$ of $\mathrm{Pd}(0.89) / \mathrm{CZ}$ having been normalised with respect to the amount of $\mathrm{NO}_{\mathrm{x}}$ adsorbed on $\mathrm{CZ}$ (Table 2). 
Fig. 7: Temperature-Programmed Desorption profiles in $\mathrm{C}_{3} \mathrm{H}_{6}-\mathrm{O}_{2}\left(1900 \mathrm{ppm}-8 \% \mathrm{O}_{2}\right.$, balance $\mathrm{N}_{2}$ ) after exposure of the catalysts to $\mathrm{NO}-\mathrm{O}_{2}\left(340 \mathrm{ppm}-8 \%\right.$, balance $\mathrm{N}_{2}$ ), at RT: (a) $\mathrm{Ce}_{0.68} \mathrm{Zr}_{0.32} \mathrm{O}_{2}(\mathrm{CZ})$, (b) $\mathrm{Pd}(0.89) / \mathrm{CZ}$.

Fig. 8: Transient $\mathrm{C}_{3} \mathrm{H}_{6}-\mathrm{O}_{2}\left(1900 \mathrm{ppm}-8 \% \mathrm{O}_{2}\right.$, balance $\left.\mathrm{N}_{2}\right)$ reaction over $\mathrm{Pd}(0.93) / \mathrm{SiO}_{2}$ and $\operatorname{Pd}(0.89) / \mathrm{Ce}_{0.68} \mathrm{Zr}_{0.32} \mathrm{O}_{2}$.

Fig. 9: Temperature-Programmed Surface Reaction profiles of $\mathrm{C}_{3} \mathrm{H}_{6}-\mathrm{NO}-\mathrm{O}_{2}(1900 \mathrm{ppm}-340$ ppm-8\%) after exposure of $\mathrm{Pd}(0.89) / \mathrm{Ce}_{0.68} \mathrm{Zr}_{0.32} \mathrm{O}_{2}$ to $\mathrm{C}_{3} \mathrm{H}_{6}-\mathrm{NO}-\mathrm{O}_{2}(1900 \mathrm{ppm}-340 \mathrm{ppm}-$ $8 \%$, balance $\mathrm{N}_{2}$ ) at RT.

Fig. 10: Steady-state catalytic conversions of $\mathrm{C}_{3} \mathrm{H}_{6}$ and $\mathrm{NO}_{x}$ to $\mathrm{N}_{2}$ in the course of the $\mathrm{C}_{3} \mathrm{H}_{6^{-}}$ NO-O ${ }_{2}$ reaction (1900 ppm- 340 ppm - 8\%, balance $\mathrm{N}_{2}$ ): (a) $\mathrm{Pd}(0.93) / \mathrm{SiO}_{2}(0.07 \mathrm{~g})$, (b) $\mathrm{Ce}_{0.68} \mathrm{Zr}_{0.32} \mathrm{O}_{2}$ (CZ, 0.20g), (c) $\mathrm{Pd}(0.54) / \mathrm{CZ}(0.20 \mathrm{~g})$, (d) $\mathrm{Pd}(0.89) / \mathrm{CZ}(0.20 \mathrm{~g})$, and of NO to $\mathrm{NO}_{2}$ over $\mathrm{Pd}(0.54) / \mathrm{CZ}(0.20 \mathrm{~g})(\mathrm{e}):(\bullet) \mathrm{NO}^{-} \mathrm{O}_{2}$ reaction $\left(340 \mathrm{ppm}-8 \%\right.$, balance $\mathrm{N}_{2}$ ), (०) $\mathrm{C}_{3} \mathrm{H}_{6}-\mathrm{NO}-\mathrm{O}_{2}$ reaction (1900 ppm- $340 \mathrm{ppm}-8 \%$, balance $\mathrm{N}_{2}$ ).

Fig. 11: Steady-state catalytic conversions of $\mathrm{C}_{3} \mathrm{H}_{6}$ and $\mathrm{NO}_{x}$ to $\mathrm{N}_{2}$ in the course of the $\mathrm{C}_{3} \mathrm{H}_{6^{-}}$ NO-O 2 reaction (1900 ppm- 340 ppm - 8\%, balance $\mathrm{N}_{2}$ ) of mechanical mixtures: (a) $\mathrm{Pd}(0.89) / \mathrm{Ce}_{0.68} \mathrm{Zr}_{0.32} \mathrm{O}_{2}+\mathrm{SiO}_{2}(0.10 \mathrm{~g}+0.10 \mathrm{~g})$, (b) $\mathrm{Pd}(0.93) / \mathrm{SiO}_{2}+\mathrm{Ce}_{0.68} \mathrm{Zr}_{0.32} \mathrm{O}_{2}(0.10 \mathrm{~g}+$ $0.10 \mathrm{~g})$ 
Fig. 12: Steady-state catalytic conversions of $\mathrm{C}_{3} \mathrm{H}_{7} \mathrm{OH}$ and $\mathrm{NO}_{x}$ to $\mathrm{N}_{2}$ in the course of the $\mathrm{C}_{3} \mathrm{H}_{7} \mathrm{OH}-\mathrm{NO}-\mathrm{O}_{2}$ reaction (2200 ppm- 340 ppm - 8\%, balance $\mathrm{N}_{2}$ ) over $\mathrm{Ce}_{0.68} \mathrm{Zr}_{0.32} \mathrm{O}_{2}(\mathrm{CZ})$.

Fig. 13: (a) Schematic representation of the catalytic functions, (b) Mechanism of the lean $\mathrm{C}_{3} \mathrm{H}_{6}$-assisted decomposition of $\mathrm{NO}$ over $\mathrm{Pd} / \mathrm{Ce}_{0.68} \mathrm{Zr}_{0.32} \mathrm{O}_{2}(\mathrm{CZ})$ catalysts, $\mathrm{O}$, $\mathrm{R}-\mathrm{NO}_{\mathrm{x}}$, $\mathrm{C}_{\mathrm{x}} \mathrm{H}_{\mathrm{y}} \mathrm{O}_{\mathrm{z}}$ representing an oxygen from the surface of the $\mathrm{CZ}$ support, organic nitrogencontaining and oxygenates compounds of undefined composition, respectively. 


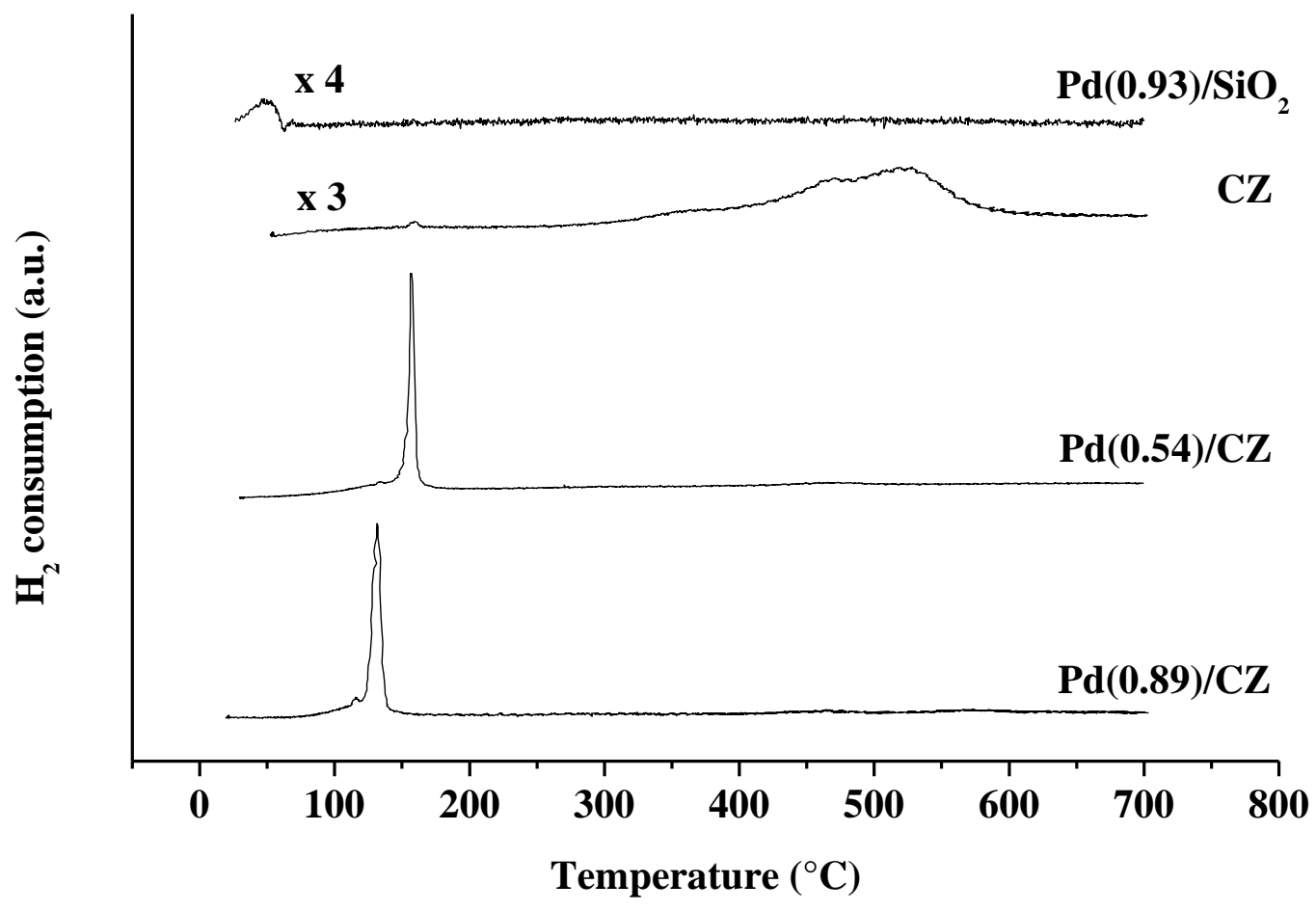

Fig. 1 


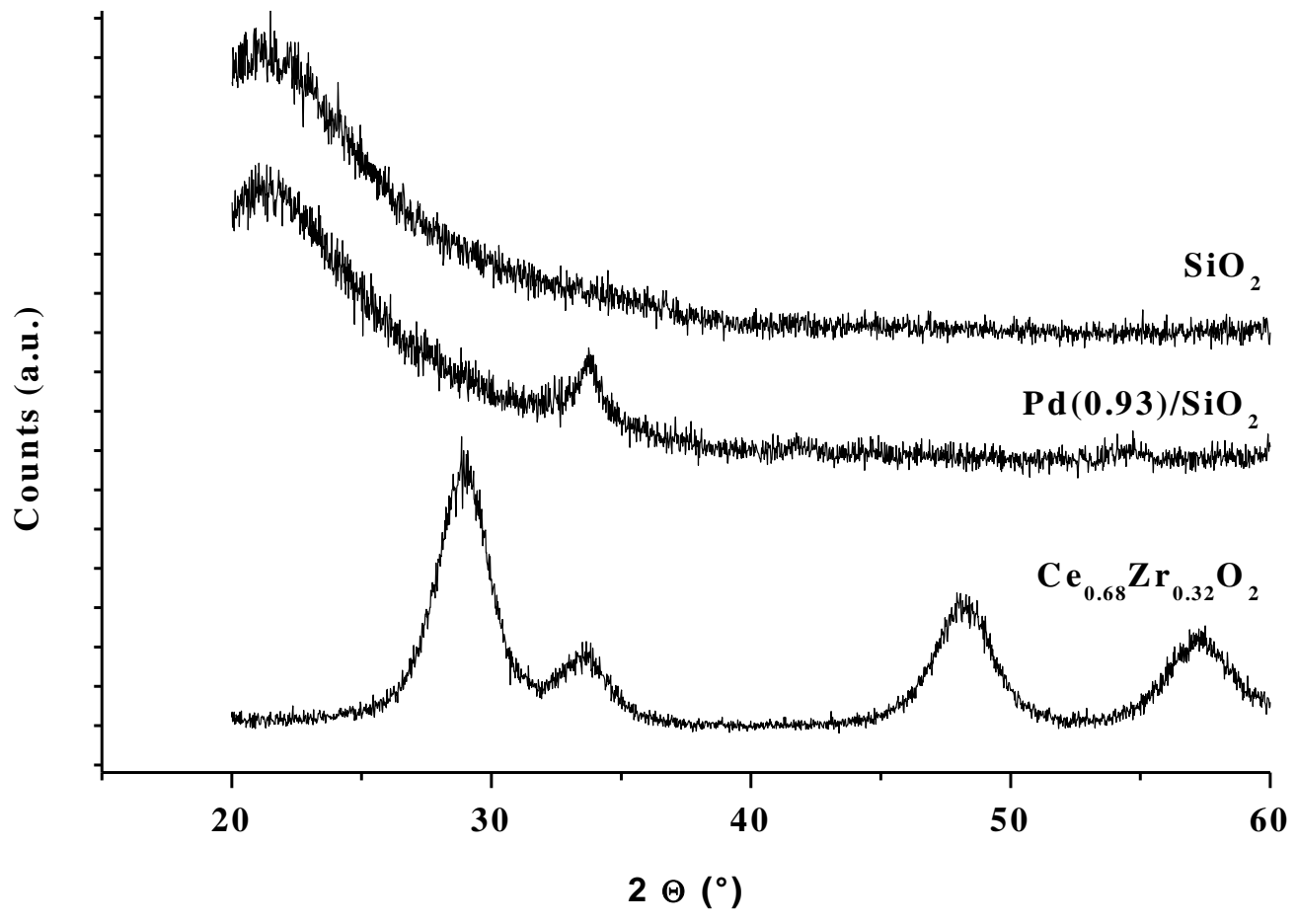

Fig. 2 


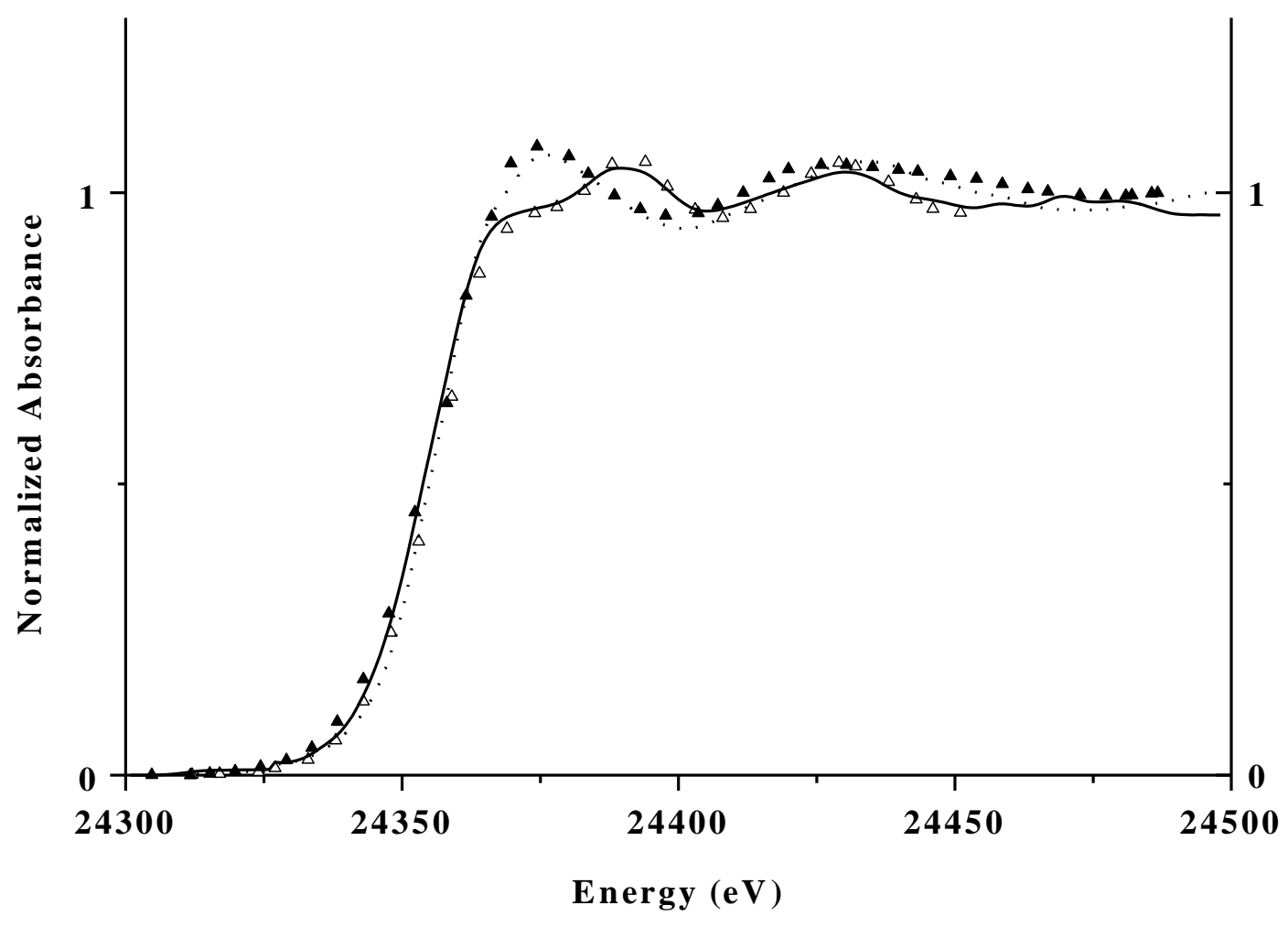

Fig. 3 
(a)

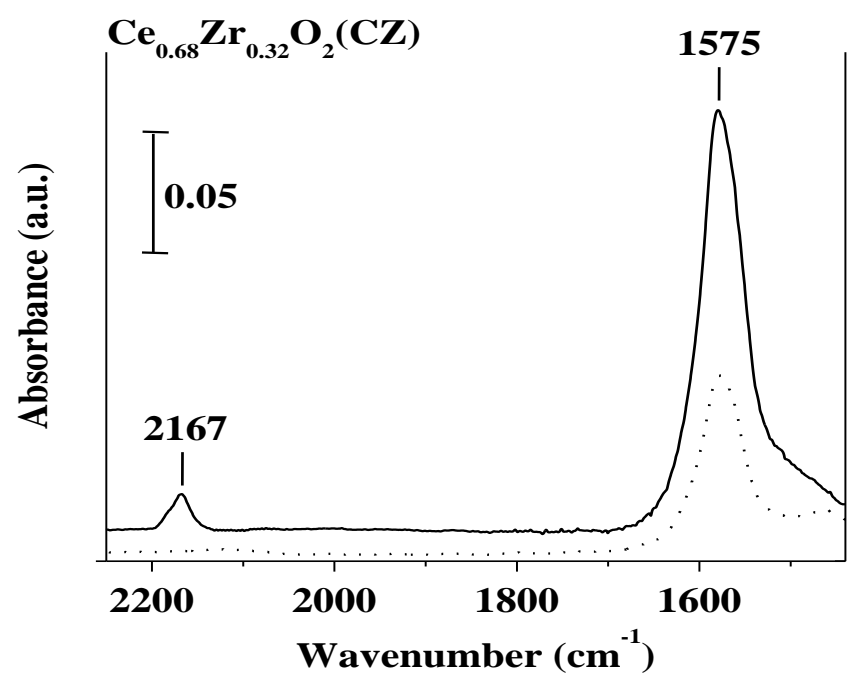

(b)

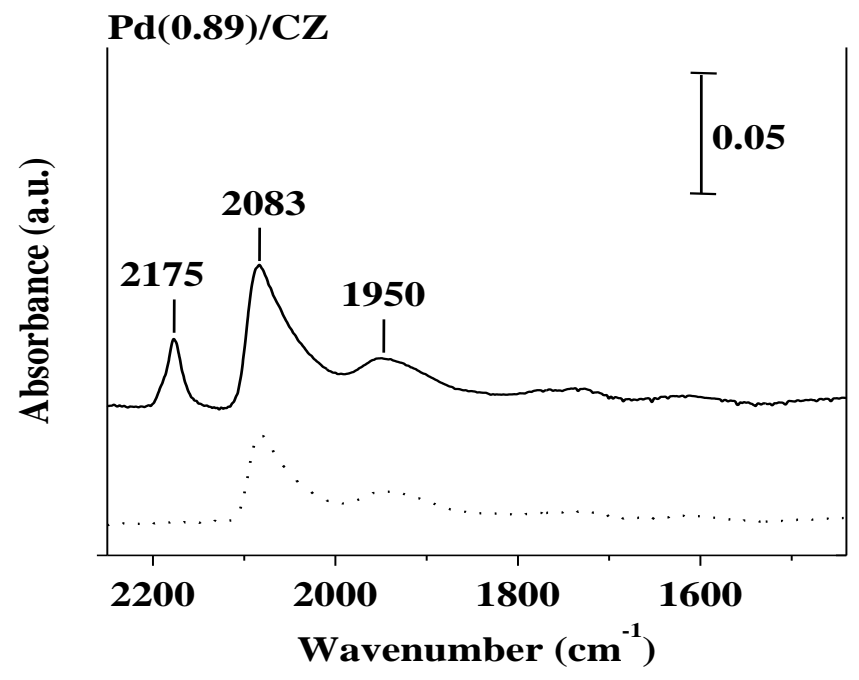

Fig. 4 


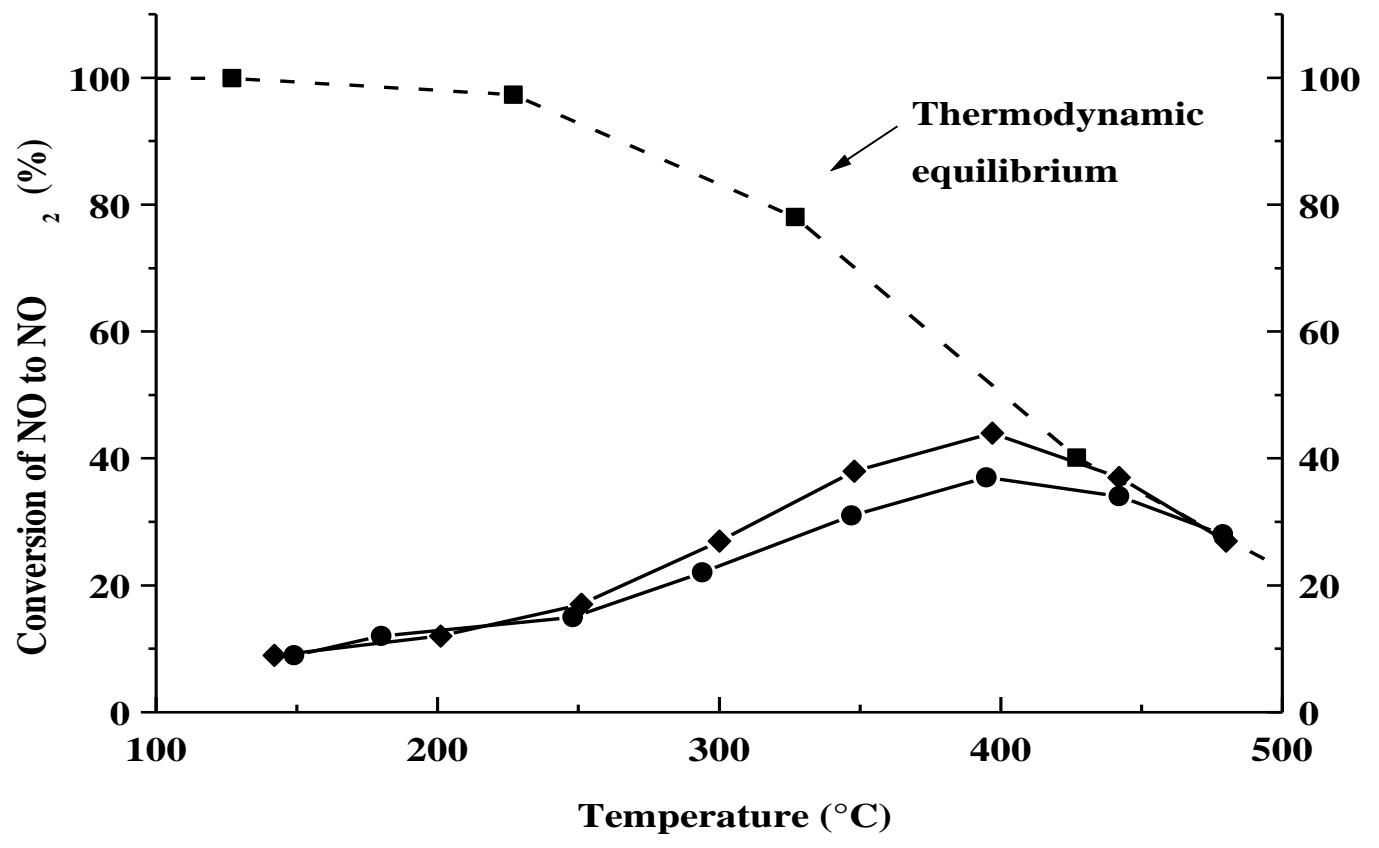

Fig. 5 

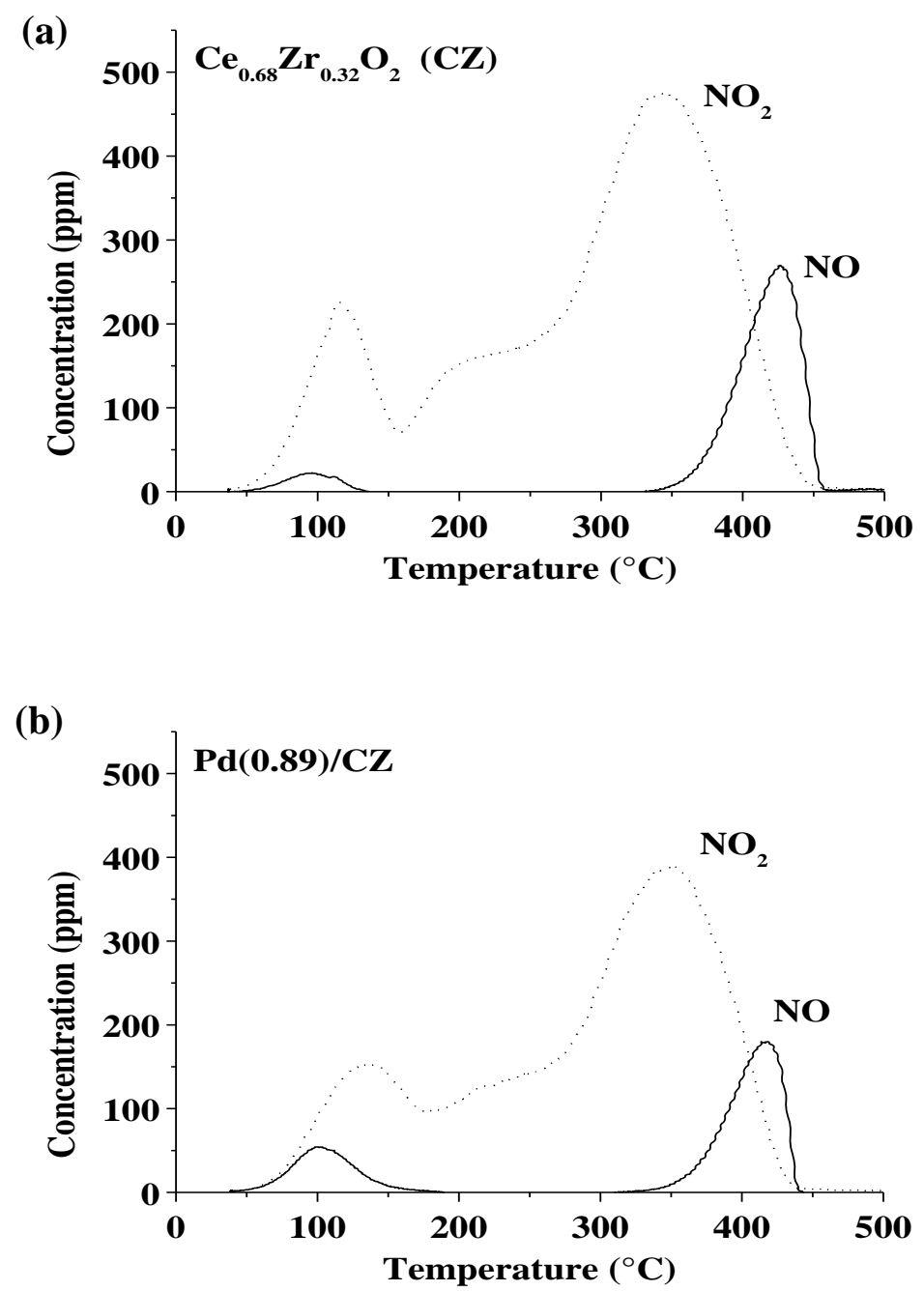

(c)

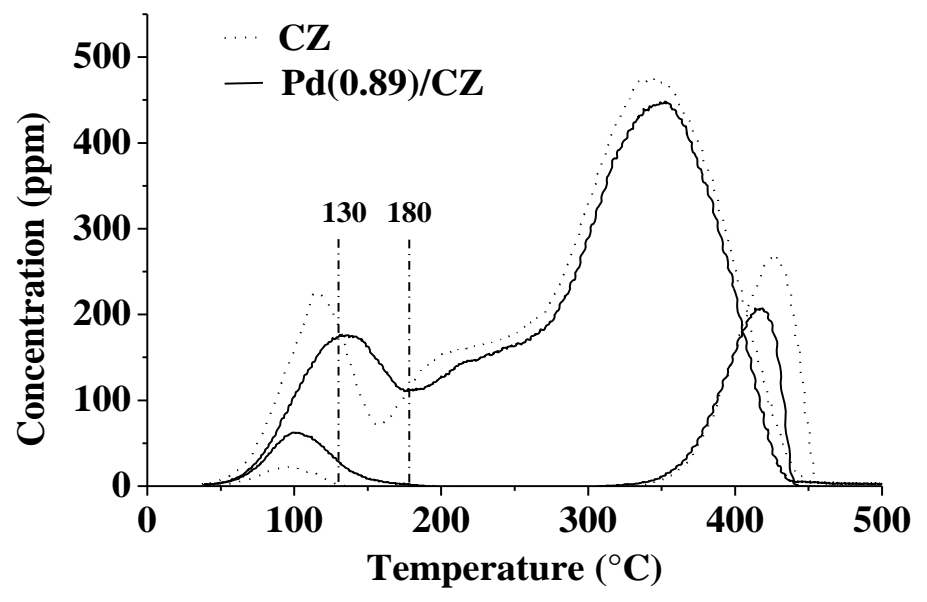

Fig. 6 

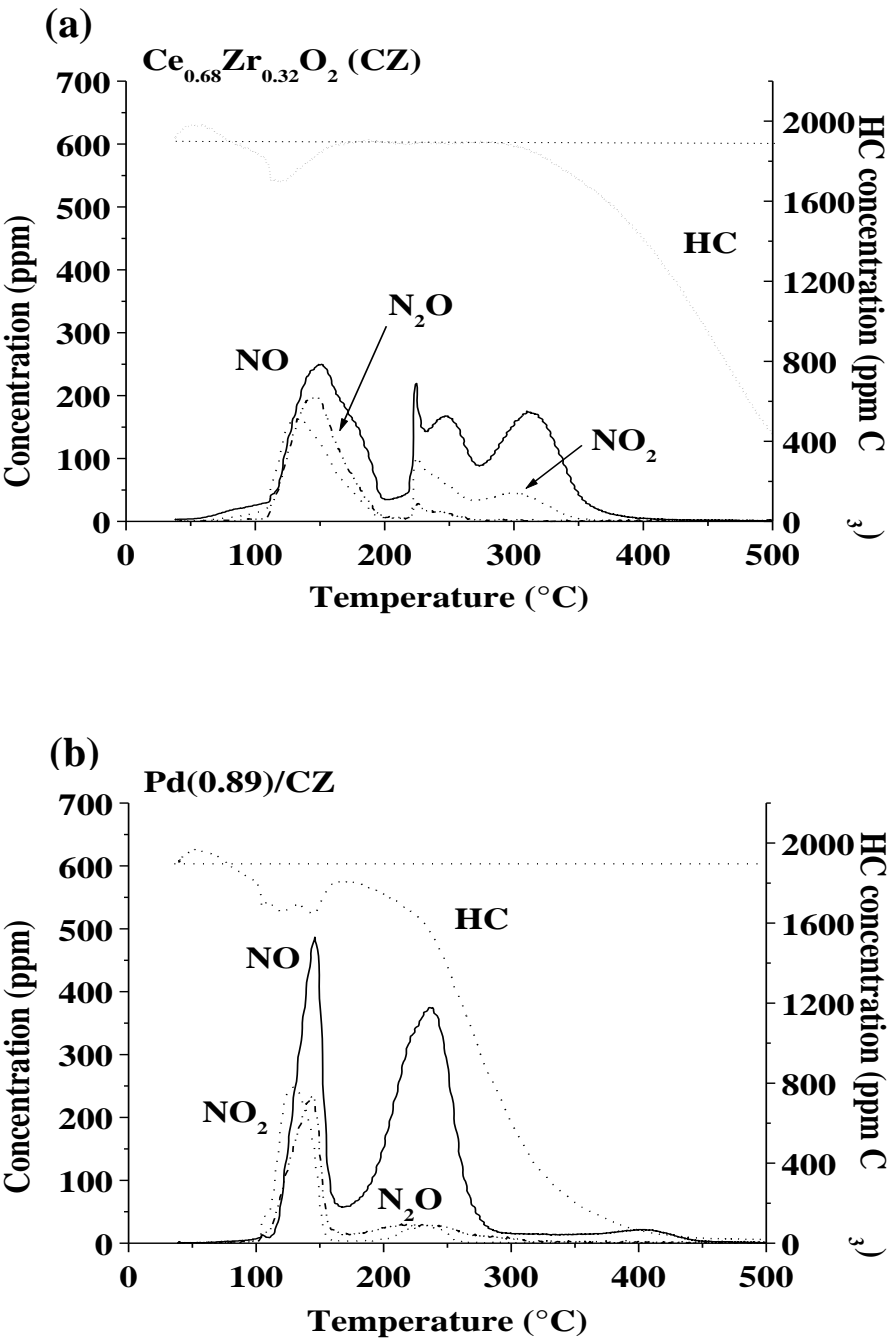

Fig. 7 


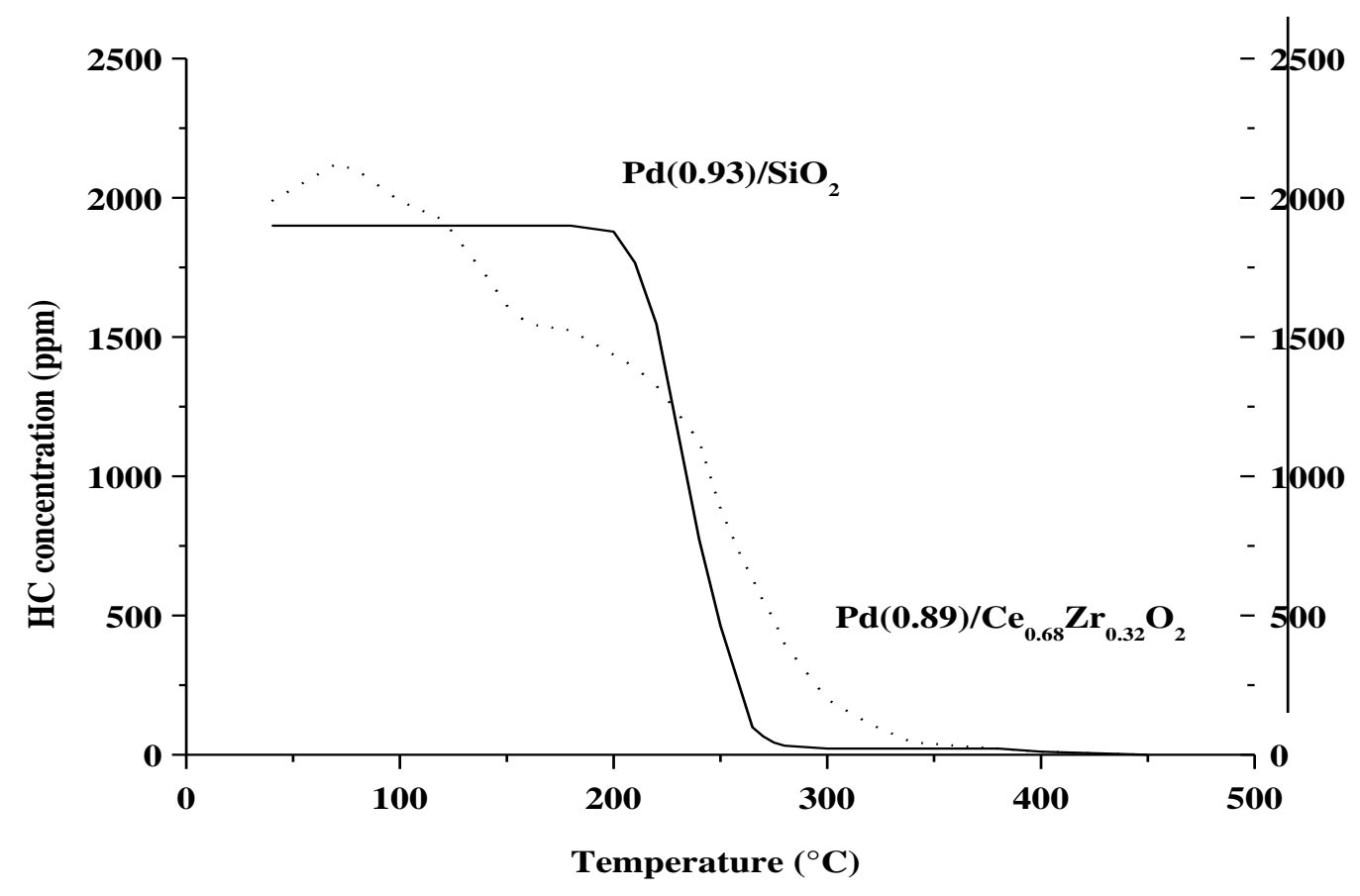

Fig. 8 


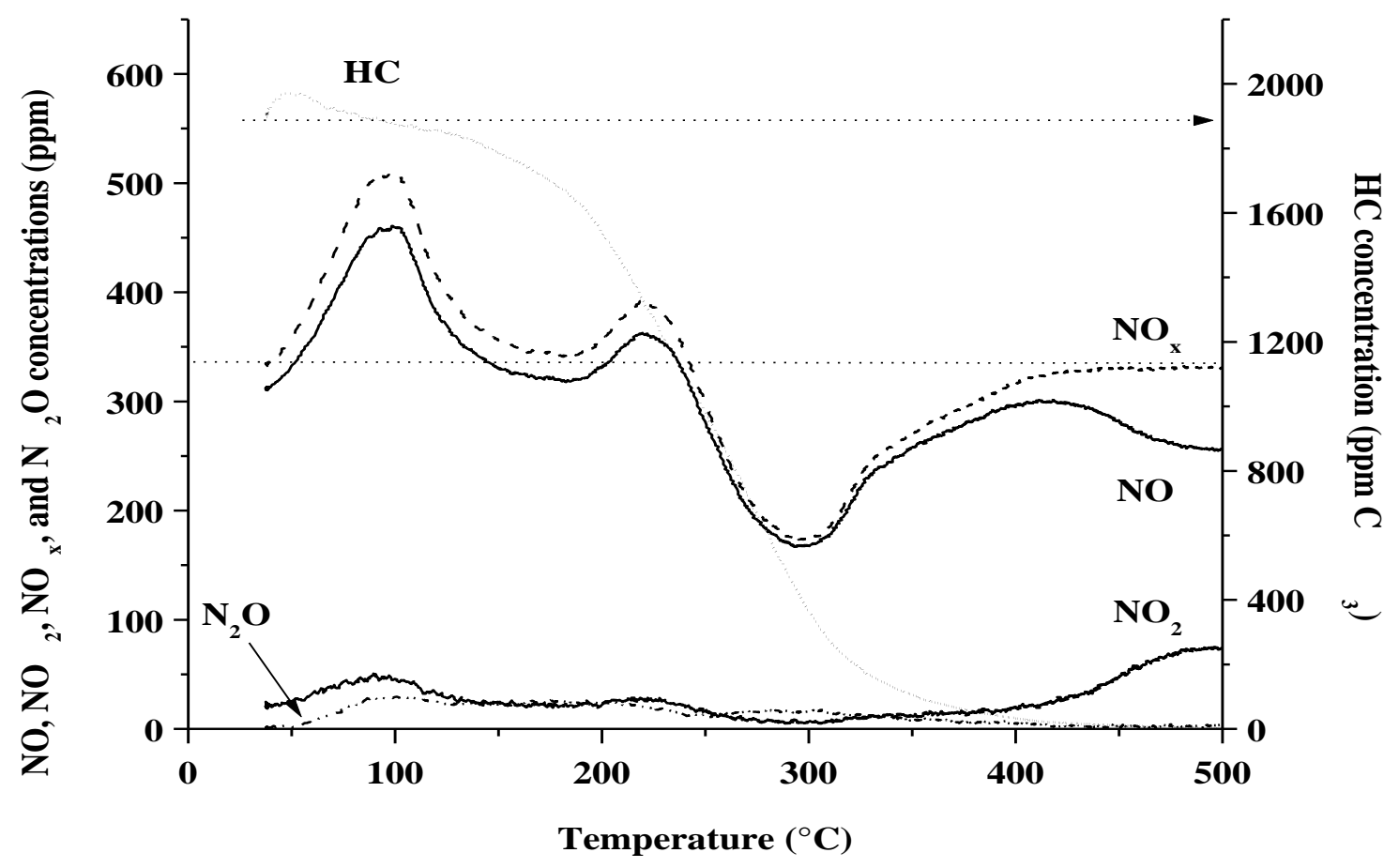

Fig. 9 

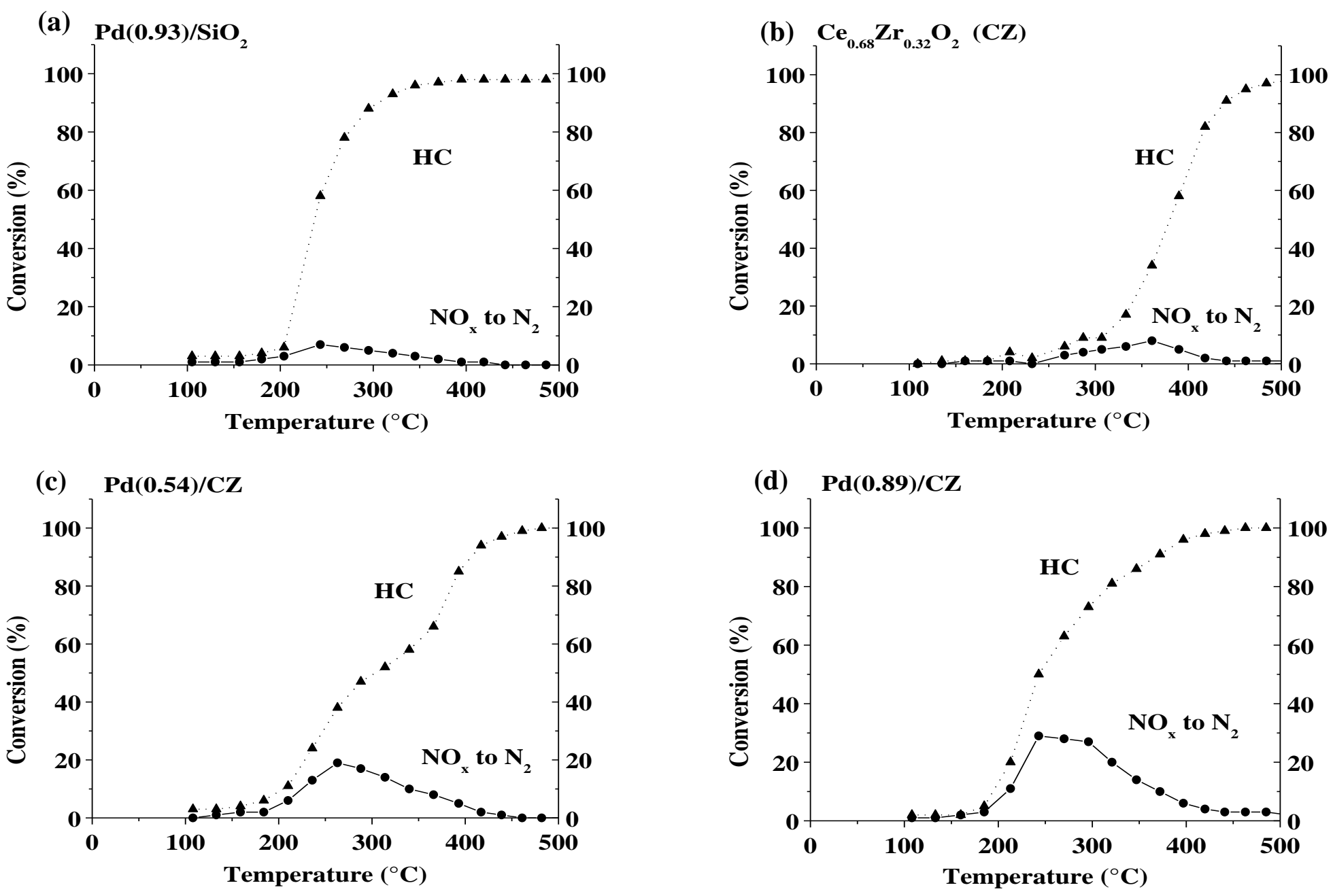

(e) $\mathrm{Pd}(0.54) / \mathrm{CZ}$

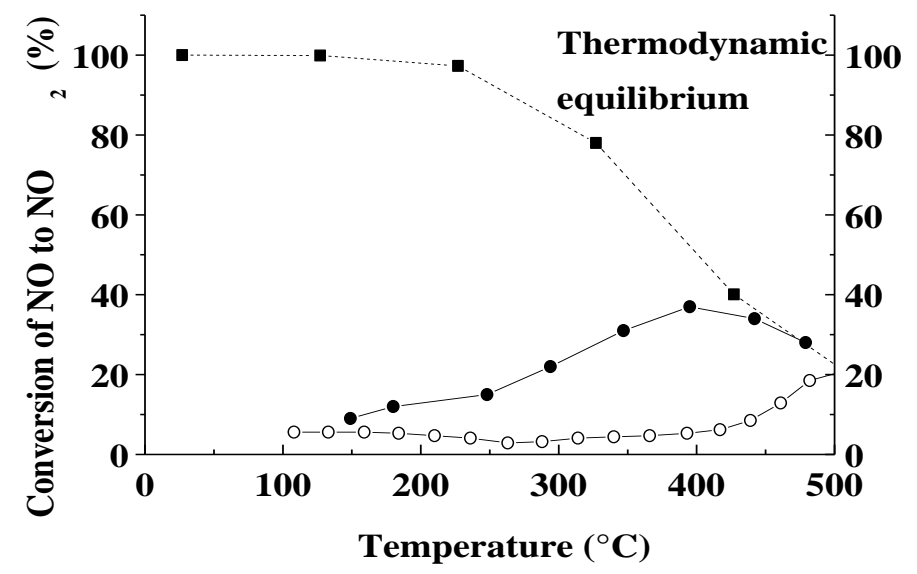

Fig. 10 
(a)

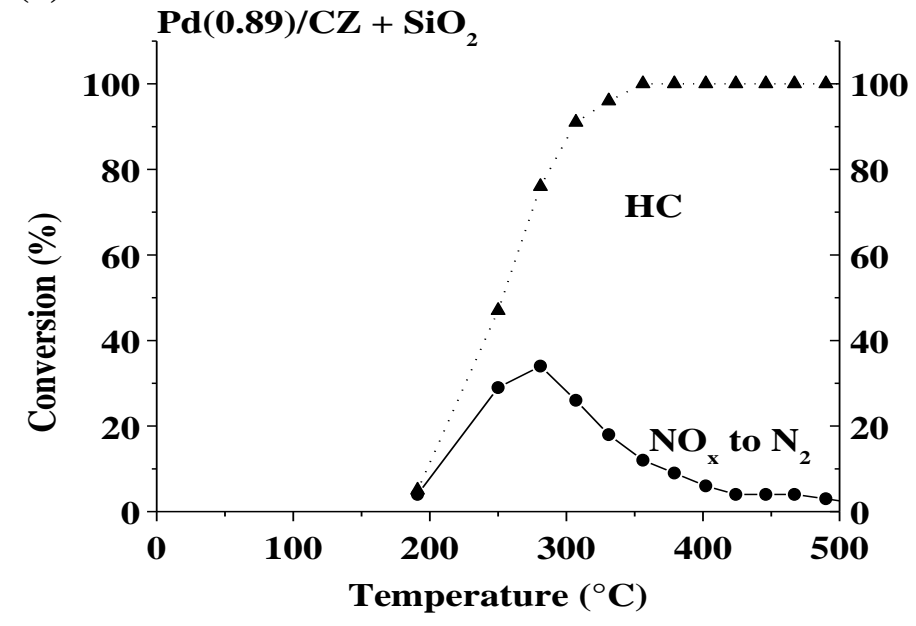

(b)

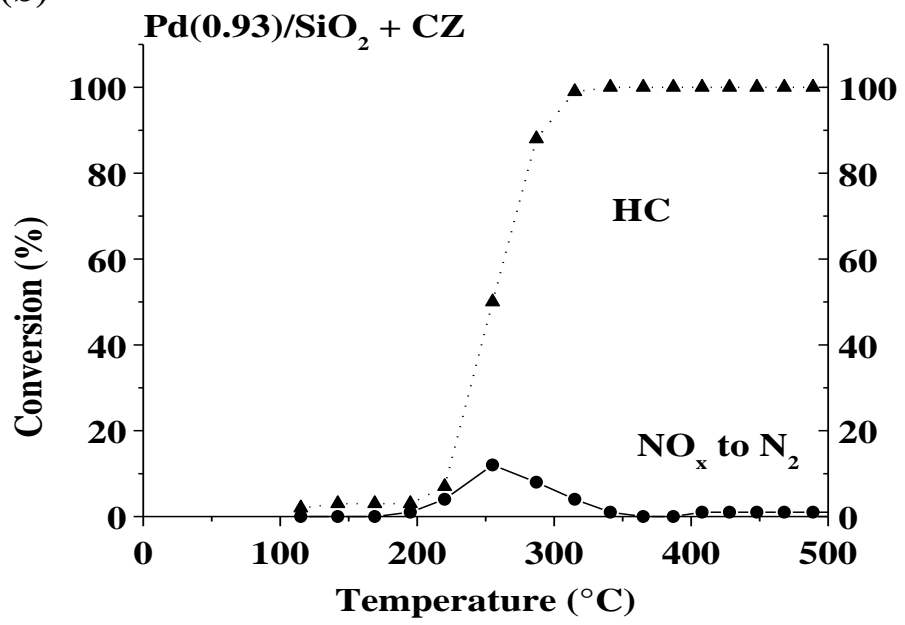

Fig. 11 


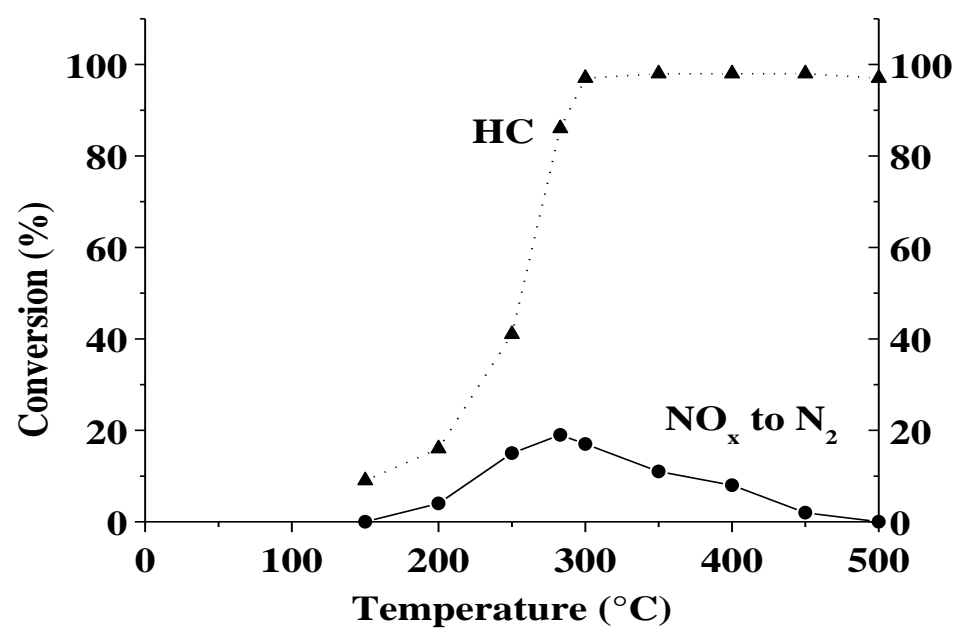

Fig. 12 
a)

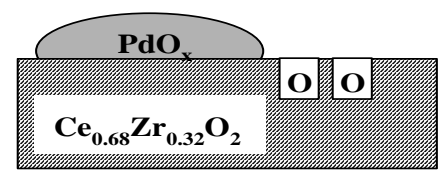

b)

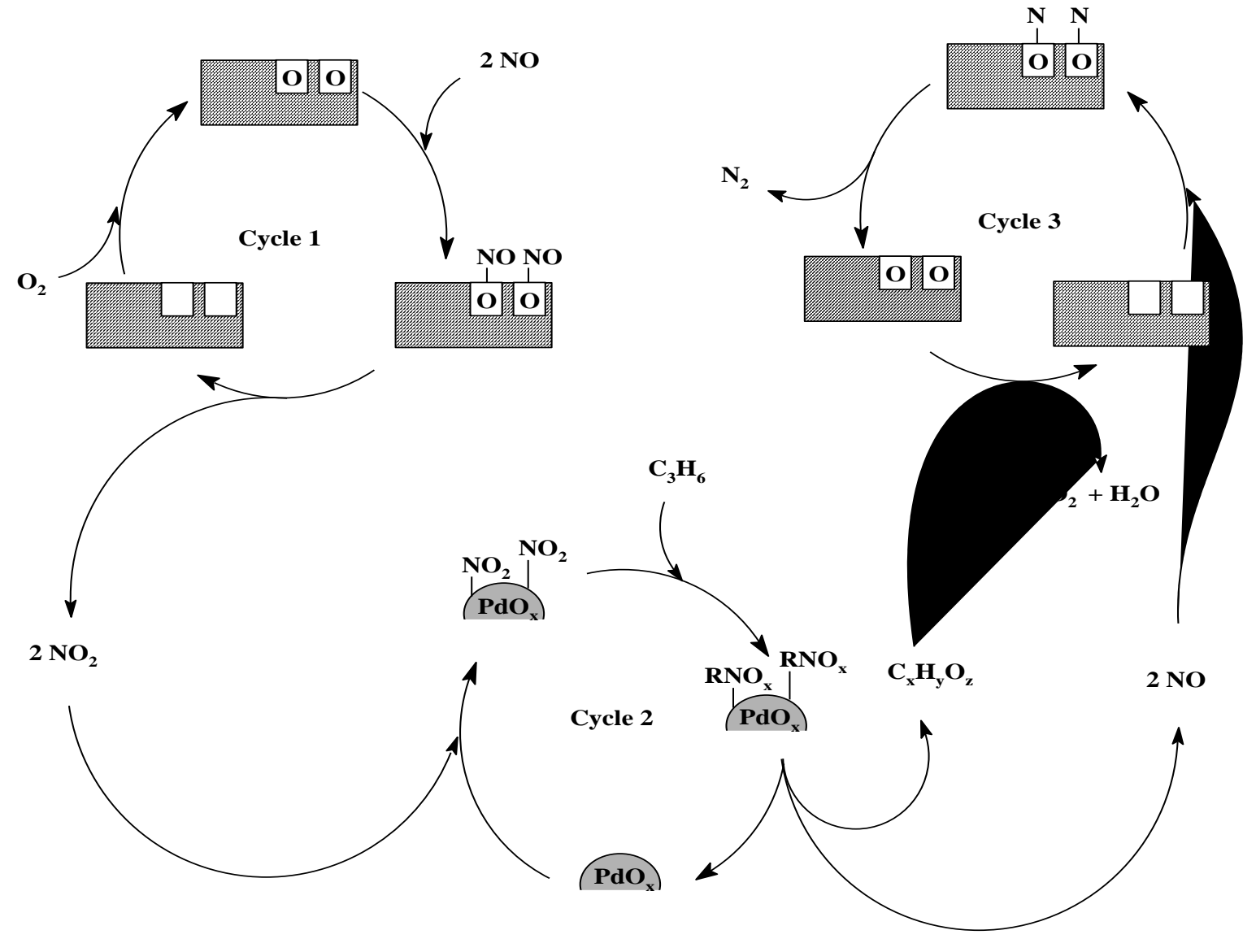

Fig. 13 